\title{
Fractalkine/CX3CL1 in Neoplastic Processes
}

\author{
Jan Korbecki ${ }^{1}{ }^{\circledR}$, Donata Simińska ${ }^{1}{ }^{\circledR}$, Klaudyna Kojder ${ }^{2}$, Szymon Grochans ${ }^{1}$, \\ Izabela Gutowska ${ }^{3}\left(\mathbb{D}\right.$, Dariusz Chlubek ${ }^{1}(\mathbb{D})$ and Irena Baranowska-Bosiacka ${ }^{1, *(1)}$ \\ 1 Department of Biochemistry and Medical Chemistry, Pomeranian Medical University in Szczecin, \\ Powstańców Wielkopolskich 72 Av., 70-111 Szczecin, Poland; jan.korbecki@onet.eu (J.K.); \\ d.siminska391@gmail.com (D.S.); szymongrochans@gmail.com (S.G.); dchlubek@pum.edu.pl (D.C.) \\ 2 Department of Anaesthesiology and Intensive Care, Pomeranian Medical University in Szczecin, \\ Unii Lubelskiej 1 St., 71-281 Szczecin, Poland; klaudynakojder@gmail.com \\ 3 Department of Medical Chemistry, Pomeranian Medical University in Szczecin, Powstańców Wlkp. 72 Av., \\ 70-111 Szczecin, Poland; izagut@poczta.onet.pl \\ * Correspondence: ika@pum.edu.pl; Tel.: +48-914-661-515
}

Received: 22 April 2020; Accepted: 21 May 2020; Published: 25 May 2020

\begin{abstract}
Fractalkine/CX3C chemokine ligand 1 (CX3CL1) is a chemokine involved in the anticancer function of lymphocytes-mainly NK cells, T cells and dendritic cells. Its increased levels in tumors improve the prognosis for cancer patients, although it is also associated with a poorer prognosis in some types of cancers, such as pancreatic ductal adenocarcinoma. This work focuses on the 'hallmarks of cancer' involving CX3CL1 and its receptor CX3CR1. First, we describe signal transduction from CX3CR1 and the role of epidermal growth factor receptor (EGFR) in this process. Next, we present the role of CX3CL1 in the context of cancer, with the focus on angiogenesis, apoptosis resistance and migration and invasion of cancer cells. In particular, we discuss perineural invasion, spinal metastasis and bone metastasis of cancers such as breast cancer, pancreatic cancer and prostate cancer. We extensively discuss the importance of CX3CL1 in the interaction with different cells in the tumor niche: tumor-associated macrophages (TAM), myeloid-derived suppressor cells (MDSC) and microglia. We present the role of CX3CL1 in the development of active human cytomegalovirus (HCMV) infection in glioblastoma multiforme (GBM) brain tumors. Finally, we discuss the possible use of CX3CL1 in immunotherapy.
\end{abstract}

Keywords: CX3CL1; fractalkine; CX3CR1; cancer; chemokine; metastasis

\section{Introduction}

It is estimated that 18.1 million people worldwide suffer from cancer each year, with 9.6 million of these ending in death [1]. In most developed countries, as cancer constitutes the most common cause of death in people under 70, neoplastic processes are being intensively studied in order to develop better and more effective therapeutic approaches. Twenty years ago, research focused mainly on changes occurring within neoplastic cells [2], especially mutations and intracellular signaling in an isolated neoplastic cell. This approach has changed along with advances in research methods, showing numerous links between cancer cells and tumor niche cells (cancer-associated fibroblasts (CAF), tumor-associated macrophages (TAM), myeloid-derived suppressor cells (MDSC), microglia, neutrophils, regulatory $\mathrm{T}$ cells $\left(\mathrm{T}_{\text {reg }}\right)$ and many others) [3,4]. These relationships are significant in the development of cancer and depend on the recruitment of cells to a cancer niche and intercellular signaling between these cells, both of which involve chemokines [5].

To date, more than 50 chemokines have been described and subsequently divided into four families, depending on the occurrence of a specific motif in the amino acid sequence at the N-terminal end. One such chemokine that plays an important role in the cancer process is CX3C chemokine 
ligand 1 (CX3CL1) along with its receptor CX3C chemokine receptor 1 (CX3CR1). This chemokine stimulates cancer cell proliferation [6-8] and participates in angiogenesis [9-11], apoptosis resistance [12] and cancer cell migration [13-16]. CX3CL1 also participates in the recruitment of cells to a cancer niche $[17,18]$. The most characteristic feature of this chemokine is its participation in organ-specific metastasis of several cancers according to 'the seed and soil' hypothesis [15,19-21].

Since the discovery of CX3CL1 more than 20 years ago [22], a number of studies on its role in cancer processes have been undertaken. However, the fragmentary nature of those reports has resulted in controversies regarding the properties and activity of this chemokine. Therefore, this paper attempts to present a comprehensive review of research on its pro- and anticancer functions.

\section{CX3CL1 Protein}

CX3CL1 is a chemokine with a cysteine signature motif -Cys-X-X-X-Cys- at the N-terminal end and is the only known representative of the $\delta$-chemokine family. It was first discovered in 1997 [22] and named neurotactin [23] and fractalkine [24], with the latter name currently in use. CX3CL1 shows high expression in the brain, where it is synthesized by neurons and has neuroprotective functions [25-28]. High expression of CX3CL1 is also found in the kidneys, lungs [29], bones [14] and blood vessels [18,30-33].

There are three main CX3CL1 transcripts ( $1.8 \mathrm{~kb}, 4 \mathrm{~kb}$ and $7 \mathrm{~kb}$ long), which are likely created by alternative splicing [29]. CX3CL1 is synthesized as a 50-75 $\mathrm{kDa}$ precursor protein [34] -as a 373-amino acid polypeptide in humans [22] and a 395-amino acid polypeptide in mice [29]. The synthesized polypeptide is glycosylated, after which CX3CL1 is built into the cell membrane and occurs on cells as $100 \mathrm{kDa}$ type I transmembrane glycoprotein [23,34]. The membrane-attached form of CX3CL1 (mCX3CL1) has a short intracellular and transmembrane domain. The most significant part of mCX3CL1 is the chemokine domain, which connects to the transmembrane domain via a mucin-like stalk [22], which does not affect the properties of mCX3CL1 but only facilitates presentation of the chemokine domain to other cells [35]. In this form, CX3CL1 acts as an adhesion protein for cells with CX3CL1 receptor expression [36], such as NK cells, CD3 ${ }^{+} \mathrm{T}$ cells, monocytes, dendritic cells and granulocytes $[24,26]$.

CX3CR1 expression is elevated in $\mathrm{CD}^{+}$and $\mathrm{CD}^{+} \mathrm{T}$ cells in exposure to interleukin 2 (IL-2). However, the expression of CX3CL1 in blood vessels is elevated by proinflammatory cytokines interferon- $\gamma$ (IFN- $\gamma$ ), tumor necrosis factor $\alpha$ (TNF- $\alpha$ ) and interleukin $1 \beta$ (IL-1 $\beta$ ) [18,30-33]. Thanks to these properties, CX3CL1 participates in the adhesion and recruitment of immune system cells to areas of a strong immune response [37]. However, this mechanism also occurs in neoplastic processes, more precisely during metastasis. Cancer cells that circulate in the blood can express CX3CR1, which allows them to adhere to mCX3CL1 in blood vessels and, consequently, to migrate to organs distant from the parent tumor $[14,19]$.

mCX3CL1 may be subject to proteolytic cleavage into soluble forms of $85 \mathrm{kDa}$ CX3CL1 (sCX3CL1) [34]. Thus far, four enzymes involved in this process have been identified: cathepsin S [38], matrix metalloproteinase (MMP)-2 [39], a disintegrin and metalloproteinase 10 (ADAM10) [39-41] and tumor necrosis factor- $\alpha$ converting enzyme/a disintegrin and metalloproteinase 17 (TACE/ADAM17) [34,39,42,43]. ADAM10 is involved in the constitutive CX3CL1 cleavage [40], while TACE/ADAM17 is involved in CX3CL1 cleavage induced by such factors as phorbol 12-myristate 13-acetate (PMA) [34,42] or proinflammatory cytokines [43]. However, in hCMEC/D3 brain endothelial cells [41] and human astrocytes [44], ADAM10 is induced by proinflammatory cytokines to mediate sCX3CL1 shedding.

\section{CX3CR1: Signal Transduction}

CX3CR1 is the receptor for CX3CL1 [45]. It belongs to seven-transmembrane domain G protein-coupled receptors. Its expression occurs in microglia, where it plays an important role in the interaction of neurons with these cells [25-27]. CX3CR1 is also expressed on immune system 
cells: NK cells, $\mathrm{CD}^{+} \mathrm{T}$ cells, monocytes, dendritic cells and granulocytes [24,26]. Expression of mCX3CL1 occurs in vessel walls and is increased by proinflammatory cytokines [18,30-33]. Thanks to the increased CX3CL1 expression, immune system cells can perform adhesion and transendothelial migration to the sites of strong immune reactions [36].

When mCX3CL1 is bound to CX3CR1, G-protein is not activated. In turn, sCX3CL1 activates its own receptor which in turn activates the $G$ protein coupled with this receptor. The signal transduction is sensitive to pertussis toxin [46], as it is dependent on $\mathrm{G}_{\mathrm{i}}$. Activating CX3CR1 activates multiple signaling pathways (Figure 1). In particular, it causes $\mathrm{Ca}^{2+}$ mobilization $[7,25]$, activation of extracellular signal-regulated kinase (ERK) mitogen-activated protein kinase (MAPK) and phosphatidylinositol-4,5-bisphosphate 3-kinase (PI3K) $\rightarrow$ Akt/protein kinase B (PKB) pathways [9,46,47], $\mathrm{Src} \rightarrow$ focal adhesion kinase (FAK) pathway $[14,16]$ and janus tyrosine kinase 2 (JAK2) $\rightarrow$ signal transducer and activator of transcription 3 (STAT3) pathway [48]. The activation of the PI3K $\rightarrow \mathrm{Akt} / \mathrm{PKB}$ pathway can activate nuclear factor $\mathrm{\kappa B}(\mathrm{NF}-\mathrm{\kappa B})$, and thus, increases apoptosis resistance; additionally, in an autocrine manner, it causes an increase in CX3CL1 expression [12,49]. JAK2 $\rightarrow$ STAT3 participates in epithelial-to-mesenchymal transition (EMT). On the other hand, activation of ERK MAPK may increase the protein expression of hypoxia-inducible factor- $1 \alpha$ (HIF-1 $\alpha$ ), and thus, supports angiogenesis [10].

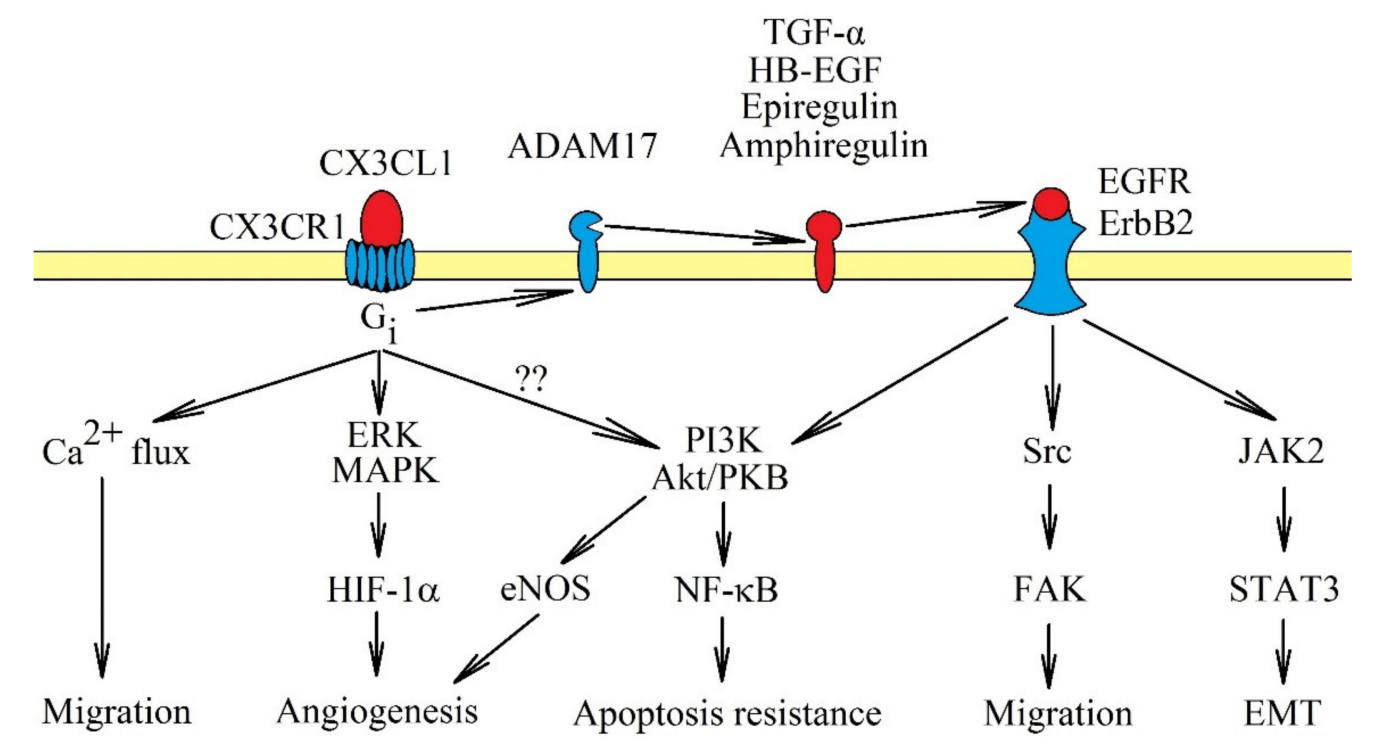

Figure 1. Signal transduction from CX3C chemokine receptor 1 (CX3CR1). The CX3CR1 receptor is a seven-transmembrane domain $G$ protein-coupled receptor. Activation of this receptor causes signal transmission to extracellular signal-regulated kinase (ERK) mitogen-activated protein kinase (MAPK) and phosphatidylinositol-4,5-bisphosphate 3-kinase (PI3K) $\rightarrow$ Akt/protein kinase B (PKB) axis, accompanied by $\mathrm{Ca}^{2+}$ mobilization. These pathways cause cancer cell migration and apoptosis resistance. CX3CR1 activation also activates Src $\rightarrow$ focal adhesion kinase (FAK) and janus tyrosine kinase 2 (JAK2) $\rightarrow$ signal transducer and activator of transcription 3 (STAT3), although it is likely that they are only activated indirectly. First, CX3CR1 activates tumor necrosis factor- $\alpha$ converting enzyme/a disintegrin and metalloproteinase 17 (TACE/ADAM17), which releases epidermal growth factor receptor (EGFR)/ErbB1 and ErbB2 receptor activators. Only after the activation of EGFR/ErbB1 and ErbB2 receptors, can Src $\rightarrow$ FAK and JAK2 $\rightarrow$ STAT3 pathways be activated as well. CX3CL1: CX3C chemokine ligand 1.

It seems that most of the pathways activated by CX3CL1, especially the Src $\rightarrow$ FAK and PI3K $\rightarrow$ Akt/PKB pathways, depend on direct activation of epidermal growth factor receptor (EGFR)/ErbB1 and ErbB2 $[7,15,50]$. The JAK2 $\rightarrow$ STAT3 pathway also highly likely depends on the activation of EGFR, as similar signal transduction occurs on breast cancer cells [51]. The activation of EGFR/ErbB1 and ErbB2 by CX3CR1 occurs through shedding and releasing of amphiregulin, epiregulin, heparin-binding 
EGF-like growth factor (HB-EGF) and transforming growth factor $\alpha$ (TGF- $\alpha$ ), all of which are EGFR/ErbB1 and ErbB2 activators [7,50,52]. In the signal transmission via CX3CR1, TACE/ADAM17 is responsible for releasing TGF- $\alpha$ [52]. TACE/ADAM17 potentially releases all ligands of the EGFR family [53], and therefore, it may be that only this proteinase is activated by CX3CR1. Thus far, there has been only one report showing the significance of TACE/ADAM17 in the activation of EGFR receptors by CX3CR1 [52].

\section{The Anticancer Response of the Immune System: The Role of CX3CL1}

One of the 'hallmarks of cancer' is the genetic instability of a cancer cell [4], which leads to the formation of new antigens triggering an immune response. Antigens allow the elimination of the cancer at an early stage of development, or to more or less effectively fight the developing tumor. An important factor in such a response is CX3CL1, participating in the anticancer response in multiple ways.

The anticancer response is characterized by increased production of IFN- $\gamma$, IL- $1 \beta$ and TNF- $\alpha-$ pro-inflammatory cytokines that increase mCX3CL1 expression in vessel walls $[31,54]$ by the activation of NF- $\mathrm{kB}$ and specificity protein 1 (Sp1) [30,32]. In addition, TNF- $\alpha$ activates p38 MAPK in blood vessel cells which then activates HuR - a protein increasing the stability of CX3CL1 mRNA and therefore CX3CL1 protein level [33]. Finally, an increase in CX3CL1 expression in a cancer cell is also induced by genetic stress caused by the accumulation of mutations that activate p53 [55].

Due to the fact that mCX3CL1 acts as an adhesion protein for cells with CX3CR1 expression, it causes the retention of immune system cells on vessel walls, close to the site of the inflammatory reaction [56-58], enabling trans-endothelial migration of these cells (Figure 2). SCX3CL1 is a chemoattractant for NK cells and dendritic cells due to CX3CR1 expression on these cells $[24,26,59]$. The expression of this receptor is also seen on $\mathrm{CD} 8^{+} \mathrm{T}$ cells and activated $\mathrm{CD} 4^{+} \mathrm{CD} 45 \mathrm{RO}^{+} \mathrm{T}$ cells [60]. However, there is no expression of CX3CR1 in eosinophils and neutrophils, and therefore, CX3CL1 does not act directly on these cells [59]. An increase in SCX3CL1 expression in the cancer microenvironment allows the chemotaxis of all the aforementioned cells with CX3CR1 expression towards the cancer niche, where they exert an anticancer effect, with $\mathrm{NK}$ cells and $\mathrm{CD}^{+} \mathrm{T}$ cells the most significant in the direct anticancer action of CX3CL1 [61-63].

In the tumor niche, the CX3CL1-CX3CR1 axis plays an important anticancer role as it allows for the migration of immature dendritic cells to the cancer cell using CX3CL1 expression [64]. This contributes to the adhesion of these two cells with each other and the maturation of dendritic cells. Mature dendritic cells show CX3CL1 expression, and in the tumor niche, this enables the migration of NK cells [65] and $\mathrm{T}$ cells [60] to mature dendritic cells. mCX3CL1 expression on mature dendritic cells enables their adhesion to NK cells or T cells along with a stronger subsequent activation of the latter. Additionally, the CX3CL1-CX3CR1 axis allows NK cells to adhere to neoplastic cells, which allows cancer cells to be more effectively killed by NK cells $[66,67]$.

CX3CL1 plays an important role in the anticancer immune response [68]. An increase in CX3CL1 expression in a tumor is correlated with the anti-cancer response of the immune system - the accumulation of anticancer $\mathrm{CD} 4^{+} \mathrm{T}$ cells, $\mathrm{CD} 8^{+} \mathrm{T}$ cells, dendritic cells and NK cells in a tumor $[61,64,69-78]$. For this reason, an increase in CX3CL1 expression in the tumor improves the prognosis for patients with breast carcinoma [74], colorectal cancer [71,79], gastric adenocarcinoma [73], glioma [78], lung adenocarcinoma [80] and soft tissue sarcomas [81]. It is even postulated using gene therapy in transferring CX3CL1 to cancer cells $[72,82]$. Out of two CX3CL1 isoforms, i.e., mCX3CL1 and SCX3CL1, the latter seems to have a strong anticancer effect [83]. mCX3CL1 has shown a weak anticancer effect, e.g., in a study on the metastasis of C26 colon cancer cells to the lung and liver, and a strong anticancer effect in a study performed in a subcutaneous tumor model [83].

CX3CL1-dependent immune processes can be offset by some mechanisms present in the tumor. For example, cancer cells increase the production of transforming growth factor $\beta$ (TGF- $\beta$ ), especially in advanced stages of cancer $[84,85]$. This anti-inflammatory cytokine, playing an important role in the development of cancer [86], reduces the expression of CX3CL1 in cancer cells [87] and cancels the action 
of pro-inflammatory cytokines on CX3CL1 expression in vessel walls [54]. TGF- $\beta$ has also a direct effect on NK cells by increasing the expression of miR-27a-5p in these cells, which causes a decrease in CX3CR1 expression, and thus, affects CX3CL1-dependent migration of these cells to the tumor niche $[88,89]$. It should be stressed, however, that the influence of cancer is not local, as the secretion of various factors by a tumor into the blood causes a general dysfunction of the immune system [90,91].

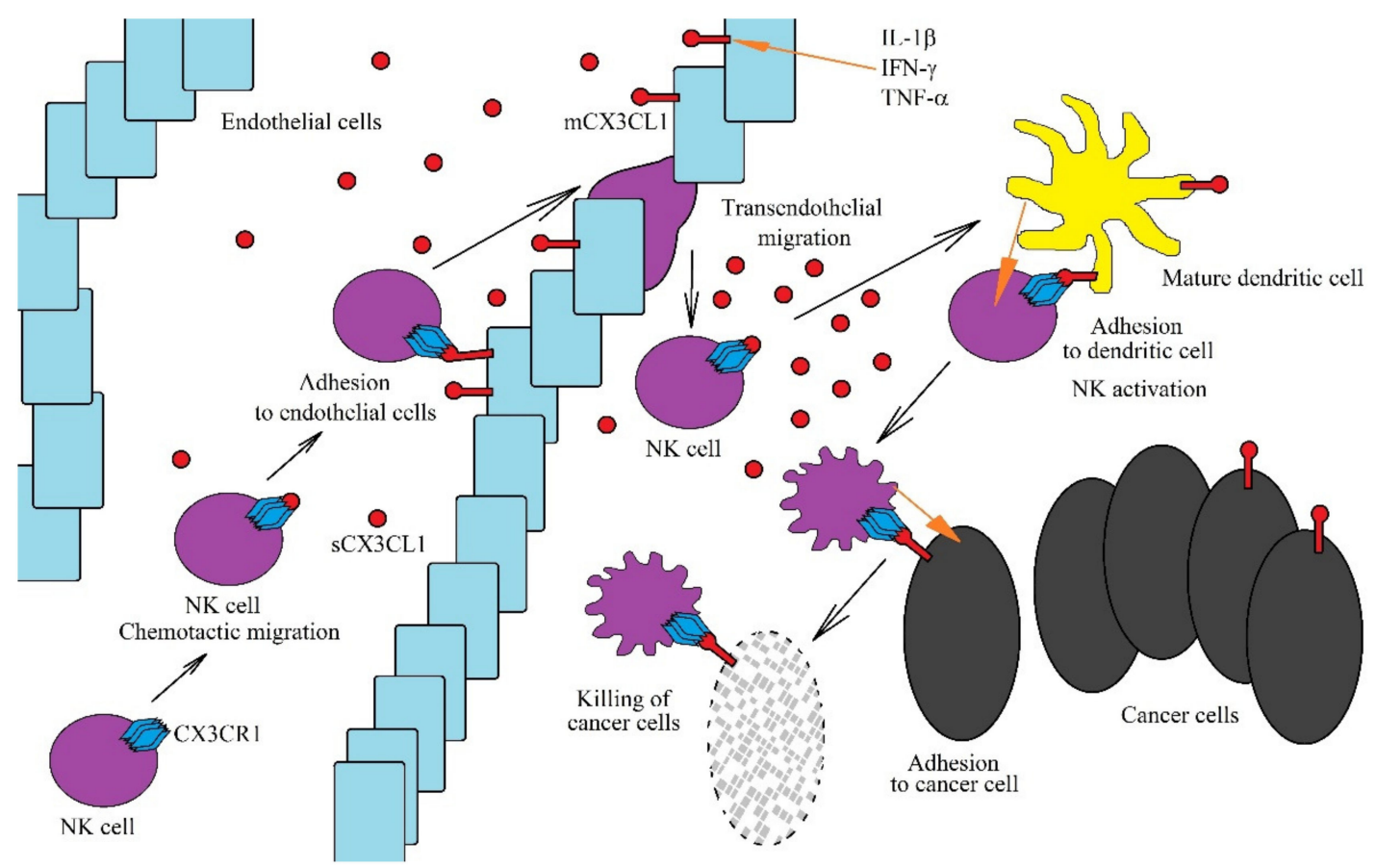

Figure 2. Role of the CX3CL1-CX3CR1 axis in anti-cancer NK cells functions. The CX3CL1-CX3CR1 axis plays an important role in the anti-tumor functions of NK cells at many levels. CX3CL1 expression is increased by the proinflammatory cytokines IL- $1 \beta$, IFN- $\gamma$ and TNF- $\alpha$. A sCX3CL1 gradient is formed, which causes chemotactic migration of NK cells. On endothelial cells near the tumor, mCX3CL1 acts as an adhesive protein for NK cells. This enables the transendothelial migration of NK cells to sites of intensive immune response, where they are activated by mature dendritic cells. However, for NK cells to be activated effectively, chemotaxis and adhesion of these cells to mature dendritic cells is required, which is dependent on the CX3CL1-CX3CR1 axis. Activated NK cells destroy cancer cells. However, in order to do this more effectively, they must adhere to cancer cells via the CX3CL1-CX3CR1 axis.

Another process that interferes with the CX3CL1-CX3CR1 axis is hypoxia. In a growing tumor, chronic hypoxia occurs because at some point the growth of the tumor is not matched by the growth of blood vessels feeding the tumor [92]. The tumor also involves another type of hypoxia, known as cycling (intermittent, transient) hypoxia. It consists of fluctuations of oxygen levels, which-depending on the type of cancer-results in alternately occurring hypoxia and reoxygenation from $15 \mathrm{~min}$ [93] to several hours [94,95]. This is associated with the abnormalities of blood vessels which do not have a hierarchical structure and show some leakiness due to weak connections between the cells [96-99]. Chronic hypoxia in a tumor impairs the normal immune response [100,101]; in particular, it abolishes the effect of proinflammatory cytokines on CX3CL1 expression [31], which inhibits the recruitment of anticancer immune system cells into the tumor niche. However, in cycling hypoxia, vascular cells show increased response to proinflammatory cytokines [102].

Another pro-cancer mechanism in a tumor is the reduction in CX3CL1 expression in a cancer cell, in particular via interfering with the functioning of p53, mainly by a mutation of the TP53 gene [103-105]. The CX3CL1 gene promoter is regulated by $\mathrm{p} 53$, and thus, the mutation in the TP53 gene reduces the expression of this chemokine in the cancer cell [55]. A neoplastic cell also shows an increase in the expression of miR-561-5p, which reduces the expression of CX3CL1 [106]. Another mechanism behind 
the reduction in the amount of $\mathrm{mCX} 3 \mathrm{CL} 1$ on a cancer cell is an increase in the expression of ADAM10 and TACE/ADAM17, enzymes releasing sCX3CL1 $[107,108]$, which results in a reduction in mCX3CL1 on a cancer cell.

CX3CL1 plays an important role in the elimination of neoplastic cells by the immune system. For this reason, many studies show a correlation between increased expression of CX3CL1 and the number of lymphocytes in the tumor and positive patient prognosis [71,73,78-81,109]. However, during the preparation of this review, we found 10 papers available in PubMed (https://www.ncbi.nlm.nih.gov/ pubmed) that concerned correlations between survival rates and CX3CL1 expression level in tumors of various cancers (Table 1). Among them, four studies show that increased expression of this chemokine in the tumor gives a worse prognosis for the patient, especially those with breast cancer [76], grades III-IV brain tumors [110], lung adenocarcinoma among tobacco smokers [111] and pancreatic ductal adenocarcinoma [112]. An increase in SCX3CL1 concentration in the blood was also associated with a worse prognosis in colorectal cancer [113]. All this shows the ambiguous effect of CX3CL1 in cancer. According to The Human Protein Atlas (https://www.proteinatlas.org/) [114], a greater expression of CX3CL1 is associated with a worse prognosis in pancreatic cancer, which is consistent with the aforementioned results of Xu et al. [112], which indicates that CX3CL1 plays an important role in the development of this particular cancer (Table 2).

Another important issue is the effect of CX3CR1 expression in a tumor on the prognosis of cancer patients. An increase in CX3CR1 expression alone may indicate an increase in the number of the cells of the immune system in a tumor and an active anti-tumor response [24,26,59-63]. Another reason for the increase in CX3CR1 expression in a tumor is an increase in the expression of this protein on a tumor cell $[19,20,79]$. In the absence of CX3CL1, this has a negative effect because if cancer cells get into the bloodstream a site-specific metastasis occurs, as described later in the article. To sum up, the increase in CX3CR1 expression in a tumor may have an either anti-cancer and pro-tumor effect, depending on the cells that express this protein.

Table 1. Prognosis for various types of cancer with increased expression of CX3CL1 or CX3CR1 according to reports available in PubMed.

\begin{tabular}{|c|c|c|c|c|}
\hline Type of Cancer & $\begin{array}{l}\text { Prognosis at Increased } \\
\text { Expression of a Given } \\
\text { Protein in Tumor }\end{array}$ & $\begin{array}{l}\text { Number of } \\
\text { Patients in } \\
\text { the Study }\end{array}$ & Comments & Source \\
\hline \multicolumn{5}{|c|}{ CX3CL1 } \\
\hline Colorectal cancer & $\downarrow$ & 174 & Plasma samples & [113] \\
\hline Colorectal Cancer & $\uparrow$ & 100 & Co-expression of CX3CL1 and CX3CR1 & [79] \\
\hline Colorectal Cancer & $\uparrow$ & 50 & & [71] \\
\hline Breast cancer & $\downarrow$ & 753 & & [76] \\
\hline Breast carcinoma & $\uparrow$ & 204 & & [74] \\
\hline Gastric adenocarcinoma & $\uparrow$ & 158 & & [73] \\
\hline Glioma & $\uparrow$ & 61 & & [78] \\
\hline Grades III-IV brain tumours & $\downarrow$ & 36 & & [110] \\
\hline Hepatocellular carcinoma & $\uparrow$ & 56 & Co-expression of CX3CL1 and CX3CR1 & [109] \\
\hline Lung adenocarcinoma & $\uparrow$ & - & From The Cancer Genome Atlas & [80] \\
\hline Lung adenocarcinoma & $\downarrow$ & 41 & Patients with smoking history & [111] \\
\hline Pancreatic ductal adenocarcinoma & $\downarrow$ & 105 & & [112] \\
\hline Soft tissue sarcomas & $\uparrow$ & 69 & Female & [81] \\
\hline \multicolumn{5}{|c|}{ CX3CR1 } \\
\hline Clear cell renal cell carcinoma & $\downarrow$ & 78 & & [46] \\
\hline Colorectal Cancer & $\uparrow$ & 100 & Co-expression of CX3CL1 and CX3CR1 & [79] \\
\hline Hepatocellular carcinoma & $\uparrow$ & 56 & Co-expression of CX3CL1 and CX3CR1 & [109] \\
\hline Epithelial ovarian carcinoma & $\downarrow$ & 557 & & [21] \\
\hline Pancreatic ductal adenocarcinoma & $\downarrow p=0.059$ & 105 & & [112] \\
\hline Pancreatic ductal adenocarcinoma & $\uparrow$ & 104 & & [20] \\
\hline
\end{tabular}

$\uparrow$-better prognosis; $\downarrow$-worse prognosis; ——no correlation 
Table 2. Prognosis for various types of cancer with increased expression of CX3CL1 or CX3CR1 according to The Human Protein Atlas [114].

\begin{tabular}{ccc}
\hline Type of Cancer & $\begin{array}{c}\text { Prognosis with Increased Expression } \\
\text { of CX3CL1 in the Tumor }\end{array}$ & $\begin{array}{c}\text { Prognosis with Increased Expression } \\
\text { of CX3CR1 in the Tumor }\end{array}$ \\
\hline Glioma & - & $\uparrow p=0.060$ \\
Thyroid cancer & $\uparrow$ & $\uparrow$ \\
Lung cancer & $\downarrow$ & $\uparrow$ \\
Colorectal cancer & - & - \\
Head and neck cancer & $\downarrow p=0.052$ & $\uparrow$ \\
Stomach cancer & $\downarrow p=0.071$ & $\downarrow$ \\
Liver cancer & $\downarrow$ & $\uparrow$ \\
Pancreatic cancer & $\uparrow$ & $\uparrow$ \\
Renal cancer & $\downarrow p=0.093$ & - \\
Urothelial cancer & $\uparrow$ & - \\
Prostate cancer & - & $\downarrow p=0.086$ \\
Testis cancer & $\uparrow$ & - \\
Breast cancer & $\uparrow$ & $\uparrow p=0.051$ \\
Cervical cancer & $\uparrow$ & $\uparrow$ \\
Endometrial cancer & - & $\downarrow$ \\
Ovarian cancer & $\uparrow$ & $\uparrow$ \\
Melanoma & $\uparrow$ & \\
\hline
\end{tabular}

$\uparrow$-better prognosis; $\downarrow$ —worse prognosis; —-no correlation

Increased expression of CX3CL1 and CX3CR1 in a tumor is both anti-cancer [24,26,59-63] and pro-cancer [6-21]. Nevertheless, relatively little is known about the effect of the co-expression of these two proteins in a tumor. Increased expression of CX3CL1 causes homing of anti-tumor cells of the immune system that express CX3CR1 [24,26,59-63]. This increases the expression of this receptor protein due to changes in the cellular composition of the tumor. If tumor cells express mCX3CL1 and CX3CR1 simultaneously, these cells will stick together [79]. This significantly impedes the migration of cancer cells. For these reasons, increasing the expression of CX3CL1 and CX3CR1 in the tumor simultaneously improves the prognosis of patients with cancers such as colorectal cancer [79] and hepatocellular carcinoma [109]. Nevertheless, in the tumor, mCX3CL1 may be cleaved by proteinases such as ADAM10 or TACE/ADAM17 [107,108], which releases the chemokine domain and thereby reduces the level of $\mathrm{mCX} 3 \mathrm{CL} 1$ on a tumor cell. For this reason, cancer cells no longer adhere to each other via CX3CR1. The receptor itself is activated by sCX3CL1 [46]. This demonstrate the pro-tumor effect of the CX3CL1-CX3CR1 axis, as discussed further in this paper [6-21]. Probably for this reason, the simultaneous increase in CX3CL1 and CX3CR1 expression would lead to a worse prognosis in patients with pancreatic ductal adenocarcinoma [112].

\section{Effects on Cancer Cell Proliferation and Apoptosis Resistance}

One of the best known 'hallmarks of cancer' is the uncontrolled proliferation and apoptosis resistance of cancer cells [2,4]. CX3CL1 stimulates the proliferation of these cells, as has been shown in breast cancer cells [7], gastric cancer cells [115], prostate cancer cells [8] and ovarian carcinomas [6,116]. However, it seems that this effect does not depend directly on CX3CR1, but on EGFR [6,7]. CX3CR1 can activate the metalloproteinase which releases the EGFR activator. The activated EGFR directly stimulates the cancer cell to proliferate.

Another pathway activated by CX3CR1 is PI3K $\rightarrow$ Akt/PKB, which activates NF- $\mathrm{BB}$ [117]. As a result, the expression of B-cell lymphoma 2 (Bcl-2) and B-cell lymphoma-extra large (Bcl- $\left.\mathrm{x}_{\mathrm{L}}\right)$ increases, which causes apoptosis resistance in pancreatic cancer cells [12]. Moreover, the activation of NF- $\mathrm{KB}$ stimulates the proliferation of pancreatic cancer cells. The activation of this transcriptional factor may also cause an increase in CX3CL1 expression, which takes place in smooth muscle cells [49], where the expression of this chemokine acts in an autocrine manner. 


\section{The role of CX3CL1 in Apoptosis in a Tumor}

Apoptosis is a consequence and at the same time a stage in the development of cancer. The high frequency of mutations and the intense proliferation of cancer cells lead to their genomic heterogeneity [118], which may result in their varied response to apoptotic conditions. In the early stages, the lack of development of blood vessels that would nourish the growing tumor results in hypoxia in the tumor, which triggers the apoptosis of those cancer cells most susceptible to adverse environmental conditions [92]. This is followed by an increase in the number of cancer cells with mutations that make them insensitive to apoptosis induction, e.g., with non-functional p53 [119,120].

The formation of apoptotic bodies intensifies tumor development [121,122] by inducing an anti-inflammatory effect and reducing the immune response [123]. Additionally, apoptotic bodies contain factors causing chemotaxis of phagocytic cells, mainly the chemotaxis of macrophages to the tumor niche. One example of such factors is sphingosine-1-phosphate (S1P) [124-126]. A second example is CX3CL1, which causes the chemotaxis of macrophages $[127,128]$ and microglia $[28,129]$. CX3CL1 from apoptotic bodies can act on TAM and influence the distribution of these cells inside the tumor, which seems to be only local, although no thorough research has been conducted in this regard. In vivo studies show that TAM recruitment is mainly the responsibility of several representatives of the $\beta$-chemokine family: monocyte chemoattractant protein 1 (MCP-1)/CC motif chemokine ligand (CCL)2 [130-133], macrophage inflammatory protein $1 \beta$ (MIP-1 $\beta$ )/CCL4 [130], regulated on activation, normally T cell expressed and secreted (RANTES)/CCL5 [134] and eotaxin-3/CCL26 [135].

CX3CL1 from apoptotic bodies also causes increased expression of milk fat globule epidermal growth factor VIII (MFG-E8) in macrophages [136]. This protein opsonizes apoptotic bodies, and thus, it participates in the removal of these particles by phagocytic cells, especially by macrophages [137]. Thanks to this, CX3CL1 increases the intensity of phagocytosis of apoptotic cells, and hence, increases the effect of these bodies on macrophages.

\section{The Role of the CX3CL1-CX3CR1 Axis on Cancer Cell Migration and Metastasis}

CX3CR1 is a chemokine receptor whose activation causes cell chemotaxis [45]. For this reason, an increase in CX3CR1 expression on cancer cells increases their migration $[14,15,138]$. The increase in CX3CR1 expression, a consequence of neoplastic processes, is further enhanced by hypoxia. The CX3CR1 gene promoter has hypoxia response elements [139], which allows HIF-1 to bind to these sequences in hypoxia, thus increasing the expression of CX3CR1. This is particularly significant in ovarian cancer cells [140], pancreatic ductal adenocarcinoma cells [139] and prostate cancer cells [141]. Under hypoxic conditions CX3CR1 expression is also increased by NF- $\mathrm{KB}$ as confirmed by research on prostate cancer cells [141]. Hypoxia is also associated with an increase in the expression of ADAM10 [142] and TACE/ADAM17 [143-145], enzymes releasing sCX3CL1, which causes the activation of CX3CR1.

The CX3CR1 gene promoter contains two Smad binding elements, thanks to which TGF- $\beta$ increases the expression of CX3CR1 in microglia [146], although more detailed research on the regulation of CX3CR1 expression by TGF- $\beta$ is required for different cancer cells. For example, one study showed that TGF- $\beta$ does not change the CX3CR1 expression level in pancreatic ductal adenocarcinoma cells [20].

The increase in CX3CR1 expression increases SCX3CL1-induced neoplastic cell migration. sCX3CL1 may come from cancer cells [147] and also from fibroblasts, which secrete this chemokine from membrane microvesicles, as shown in prostate cancer models [148]. The activation of CX3CR1 activates multiple signaling pathways, in particular the Src $\rightarrow$ FAK pathway in breast cancer cells [14], lung cancer cells [16], pancreatic ductal adenocarcinoma cells [13] and in prostate cancer cells [15]. However, it seems that the $\mathrm{Src} \rightarrow$ FAK pathway is only indirectly activated via CX3CR1. This receptor activates EGFR, which is directly responsible for the activation of the Src $\rightarrow$ FAK pathway and cancer cell migration, as shown on prostate cancer cells [15]. Apart from this pathway, CX3CR1-induced migration also crucially involves p38 MAPK, ERK MAPK and the PI3K $\rightarrow$ Akt/PKB axis [149].

Activation of CX3CR1 causes EMT in pancreatic ductal adenocarcinoma [48] and prostate cancer cells [52]. This effect depends on the activation of JAK2 $\rightarrow$ STAT3 in pancreatic ductal adenocarcinoma 
cells [48]. It has been shown that it is also dependent on the release of amphiregulins, HB-EGF and TGF- $\alpha$, and the activations of EGFR/ErbB1 receptors on prostate cancer cells [52] and EGFR/ErbB1 and ErbB2 on breast cancer cells [7]. The EGFR family-dependent migration of cancer cells induced by CX3CR1 activation is probably a single signaling pathway, since the activation of STAT3 can take place via EGFR/ErbB1 [51]. However, further research on the exact mechanism and the role of EGFR family in EMT induced by CX3CR1 activation is required.

The activation of CX3CR1 also increases the expression of MMP-9 [15,111] and MMP-2 [111], metalloproteinases which participate in migration and angiogenesis.

The growth of the tumor is accompanied by the emergence of mechanisms that induce the migration of tumor cells. It is estimated that as many as 1 million cancer cells are released daily into the blood from just $1 \mathrm{~g}$ of cancer tissue [150]. In the bloodstream, the circulating cancer cells show low viability due to many factors, e.g., lack of attachment to the extracellular matrix, which causes anoikis [151]. However, circulating cancer cells are disseminated throughout the bloodstream, adhere to the blood vessels, and consequently, form a tumor in an organ other than that from which the cancer cells originate [152]. This process, known as metastasis, involves mCX3CL1 as one of the adhesion proteins. Due to the high expression of CX3CL1 in bones [14], lungs [29] and nervous tissues [25-28], circulating cancer cells with CX3CR1 expression cause metastasis in these organs and tissues (Figure 3). For this reason, breast cancer often causes metastases to spinal cancellous bone, bones [14,153,154] and brain [155], osteosarcoma to the lungs [117], while ovarian carcinoma is associated with peritoneal metastasis [6,21], pancreatic ductal adenocarcinoma causes perineural invasion $[13,20,139,156]$ and prostate cancer causes bone metastasis $[15,19,47]$. Particularly in prostate cancer, high levels of dihydrotestosterone increase the cleavage of mCX3CL1 in bones [19], which causes a release of SCX3CL1 and the migration of prostate cancer cells to the bone marrow.

CX3CL1 can participate in so-called inflammatory oncotaxis, a process that involves the formation of metastasis at the site of inflammation caused by mechanical trauma [157,158]. Ischemia-reperfusion brain injury [159,160], skin wounds [161] and arterial injuries [162] induce greater production of CX3CL1. This process participates in the healing of damaged tissue. However, it can also take part in metastasis. The large majority of circulating cancer cells will not form a tumor because the subsequent stages of metastasis depend on many factors and are highly ineffective. Some of these factors are chemotactic agents secreted from wounds and adhesion proteins near damaged blood vessels, for example, mCX3CL1. Therefore, it can be assumed that this chemokine supports skin metastasis in wounds [163-165] or the migration of glioblastoma multiforme (GBM) cells to stroke areas $[87,166]$. At these sites, neoplastic cells find favorable conditions for further development and form a metastasis [167]. These are just general premises of the potential role of the CX3CL1-CX3CR1 axis in inflammatory oncotaxis, and need to be backed by experimental research.

The CX3CL1-CX3CR1 axis may also indirectly participate in organ-specific metastasis, where it may cause increased surface expression of CXC motif chemokine receptor 4 (CXCR4) on chronic lymphocytic leukemia cells [149]. This process is dependent on the activation of the PI3K $\rightarrow \mathrm{Akt} / \mathrm{PKB}$ pathway, but the exact mechanism has not yet been determined. In general, Akt/PKB activation increases CXCR4 expression at the transcription level $[168,169]$, a process which may depend on Akt/PKB $\rightarrow$ NF-kB [170] or Akt/PKB $\rightarrow$ mTOR [171] depending on the experimental model. Therefore, it may be postulated that CX3CL1 causes an increase in CXCR4 expression through one of these pathways. The increased expression and activation of CXCR4 is necessary for bone marrow metastasis [172] - as the high expression of CXC motif chemokine ligand (CXCL) 12 in the bone causes the homing of only those cells which have CXCR4 expression. Additionally, the activation of CX3CR1 on human myeloma RPMI-8226 cells increases their adhesion to fibronectin and vascular cell adhesion molecule-1 (VCAM-1) [173], which is associated with the migration of these cells to bone marrow. 


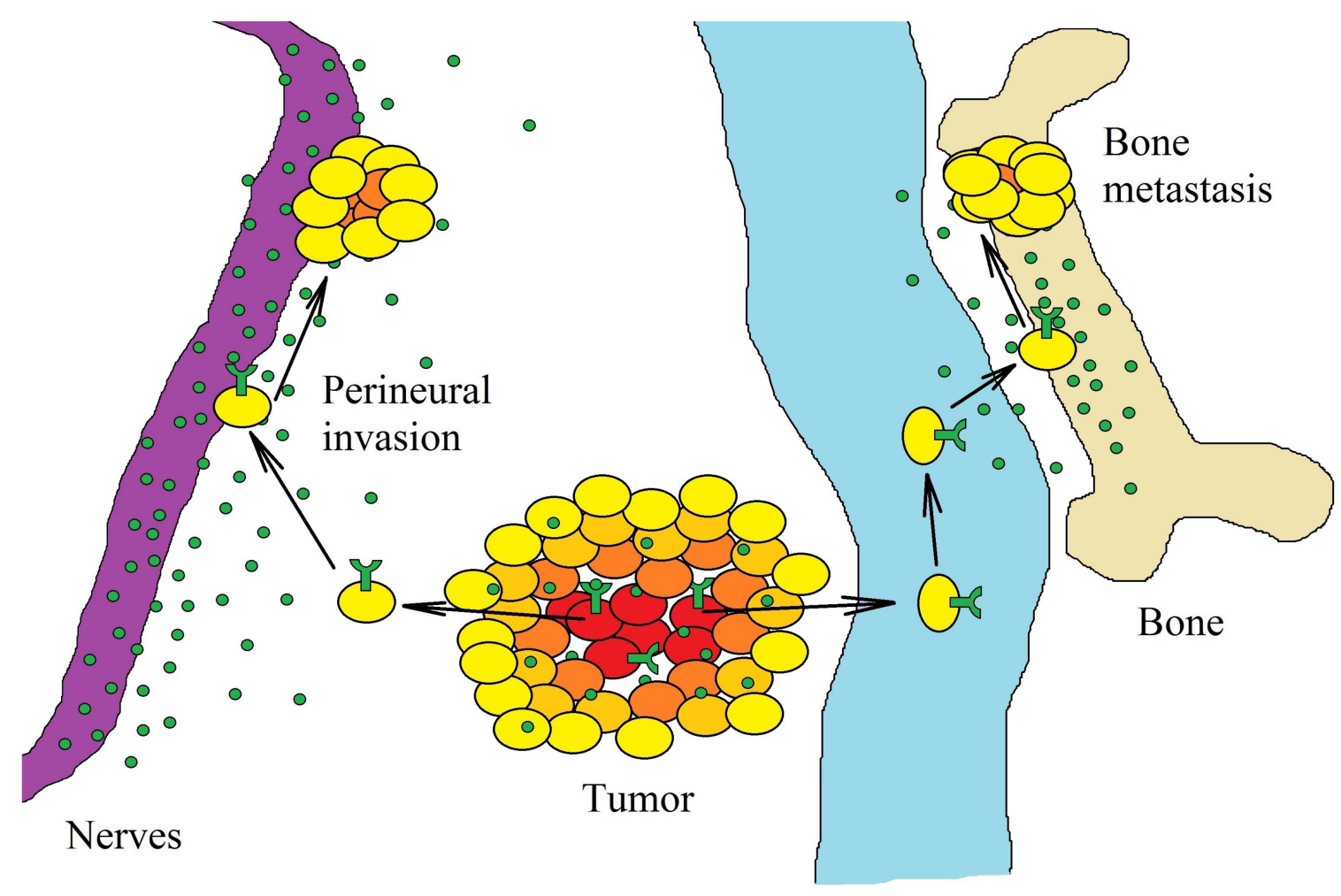

Blood Vessels

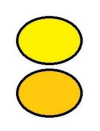

\section{Cancer cells} under normoxic condition

\section{y $\mathrm{CX} 3 \mathrm{CR} 1$ - CX3CL1}

Figure 3. Significance of the CX3CL1-CX3CR1 axis in hypoxia-induced metastasis. Hypoxia induces an increase in CX3CR1 expression on cancer cells. The increased concentration of CX3CL1 in the tumor causes the migration of tumor cells. A neoplastic cell with CX3CR1 expression migrates to areas with a high CX3CL1 concentration within the same organ. Because neurons are one of the sources of this chemokine, perineural invasion may occur, often in pancreatic ductal adenocarcinoma. In the bloodstream, on the other hand, cancer cells with CX3CR1 expression migrate to the brain and bones-organs with a high expression of CX3CL1.

CX3CL1-CX3CR1 axis stimulates cancer cell migration, although it can also inhibit migration. As mCX3CL1 is an adhesion protein for cells with CX3CR1 expression, cancer with a simultaneous expression of both these proteins may aggregate, and thus, the migration of these cells is prevented [79]. This process is significant in a GBM tumor [87], characterized by high expressions of CX3CR1 [174-176] and CX3CL1 [147]. CX3CL1 expression is inversely controlled by TGF- $\beta$ [87], with a higher concentration of TGF- $\beta$ reducing the expression of CX3CL1 and increasing the migration of GBM cells.

\section{The Role of CX3CL1 in Angiogenesis: Influence on Endothelial Cells}

Blood vessels do not grow commensurately with the tumor, which inevitably results in hypoxia in the tumor, triggering reactions that stimulate angiogenesis [177-179], a complex process in the tumor microenvironment involving many signal particles and cell types [180]. Two of the most significant are vascular endothelial growth factor (VEGF) [181] and TAM [182]. There are also many smaller signal molecules that participate in angiogenesis in the tumor. One such molecule is CX3CL1. Studies show that the CX3CL1-CX3CR1 axis is important in the angiogenesis of tumors such as breast 
cancer [183], hepatocellular carcinoma [184], lung cancer [185], malignant melanoma [186] and multiple myeloma [187].

CX3CL1-CX3CR1 influences angiogenesis in two ways. CX3CL1 participates in the recruitment of pro-angiogenic TAM $[183,188]$. CX3CL1 may also directly affect endothelial cells, causing their proliferation, migration and tube formation [9-11] (Figure 4). The latter process may intensify in hypoxia, a state shown to increase the expression of CX3CL1 in human umbilical vein endothelial cells (HUVEC) [189] and prostate cancer cells [8]. The exact mechanisms of the effect of CX3CL1 on endothelial cells vary. In human aortic endothelial cells, activation of CX3CR1 causes the activation of ERK MAPK, followed by an increase in HIF-1 $\alpha$ protein expression and the production of VEGF-A 165 but not VEGF-D [10]. Then, VEGF-A 165 causes angiogenesis. In contrast, a study on HUVEC showed that CX3CL1 does not cause VEGF-dependent angiogenesis. CX3CL1 at $10 \mathrm{ng} / \mathrm{mL}(0.33 \mathrm{nM})$ activated two pathways in those cells: ERK MAPK and PI3K $\rightarrow$ Akt/PKB $\rightarrow$ endothelial nitric oxide synthase $(\mathrm{eNOS}) \rightarrow$ nitric oxide (NO) [9]. This resulted in the stimulation of proliferation, migration and tube formation of HUVEC. However, at a concentration of $300 \mathrm{ng} / \mathrm{mL}(10 \mathrm{nM})$, CX3CL1 in HUVEC and human microvascular endothelial cells did not activate Akt/PKB but only c-Jun N-terminal kinase (JNK) and ERK MAPK, MAPK kinases responsible for the migration of endothelial cells [11]. Significantly, the concentration of $300 \mathrm{ng} / \mathrm{mL}(10 \mathrm{nM})$ is much higher than the physiological level [190], and thus, this model may not show the real mechanisms in which CX3CL1 participates. Another problem is the participation of EGFR/ErbB1 in signal transduction from CX3CR1. In a research model of primary human coronary artery smooth muscle cells, CX3CR1 directly activated ERK MAPK via $G_{i}$. However, the activation of the PI3K $\rightarrow$ Akt/PKB pathway was dependent on EGFR/ErbB1 [50] and the shedding of epiregulin. Probably, in endothelial cells, CX3CL1 causes the activation of EGFR/ErbB1; this receptor directly participates in angiogenesis.

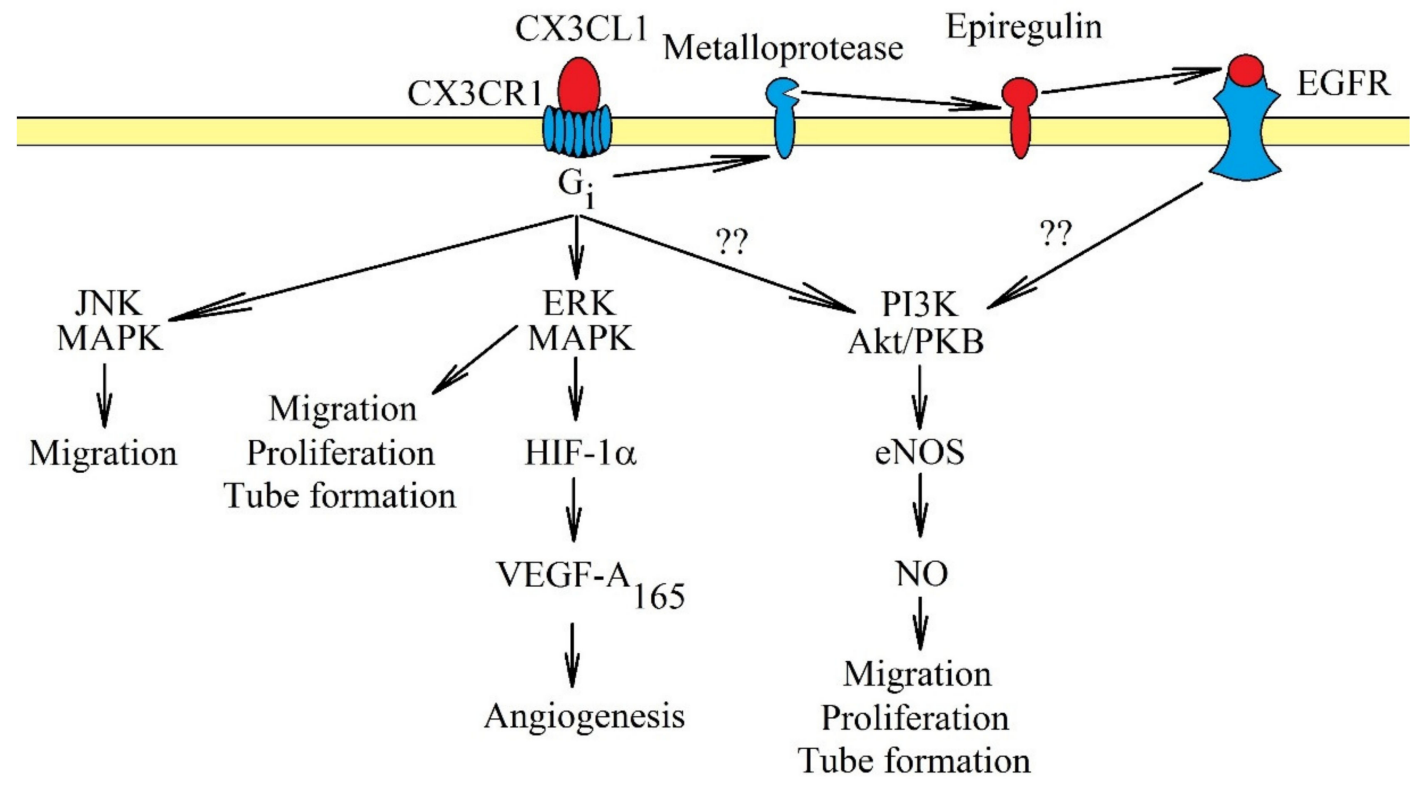

Figure 4. Intracellular signaling in endothelial cells in the induction of angiogenesis by CX3CL1. Activation of CX3CR1 causes signal transduction in endothelial cells, which causes angiogenesis. The most important activated pathways in this process are ERK MAPK and PI3K $\rightarrow$ Akt/PKB. Activation of ERK MAPK causes migration, proliferation and tube formation of endothelial cells. This MAPK cascade may also participate indirectly in angiogenesis and increase the expression of HIF- $1 \alpha$, responsible for increasing VEGF- $\mathrm{A}_{165}$ production. This growth factor participates directly in angiogenesis. Another pathway activated by CX3CR1 is PI3K $\rightarrow$ Akt/PKB, which in turn increases the activation of eNOS and NO production. It is likely that it is activated directly by EGFR, and CX3CR1 plays only an indirect role. Another important pathway in angiogenesis caused by CX3CR1 activation is JNK MAPK. Activation of this cascade causes migration of endothelial cells. 


\section{Recruitment of Macrophages by the CX3CL1-CX3CR1 Axis}

Tumors also contain macrophages, which are recruited blood monocytes [182]. During the recruitment process, monocytes are differentiated into macrophages with specific characteristics. Intensive inflammatory reactions result in the differentiation of monocytes into M1 phenotype macrophages [191], pro-inflammatory macrophages with low CX3CR1 expression. Accumulation of these cells in the tumor improves the prognosis of patients with glioma [192]. However, in the tumor there are also factors inhibiting immune reactions, resulting in the differentiation of monocytes into M2 phenotype macrophages and TAM [191]. Macrophages with these two phenotypes have a high expression of CX3CR1 [191], and a high percentage of these cells is associated with a poor prognosis [192]. However, it seems that the polarization of macrophages is flexible [193] and largely depends on factors affecting the macrophages at a given moment.

Monocytes are recruited to the tumor niche by chemokines. Most often, these cells are recruited by MCP-1/CCL2 [130-133,194], MIP-1ß/CCL4 [130] and RANTES/CCL5 [134,194]. Additionally, the recruitment of monocytes through CX3CL1 occurs in in vivo models of such cancers as human breast cancer line HS578T [183], human colorectal adenocarcinoma line DLD1 [18] and human colorectal carcinoma line HCT116 [18]. It seems that this CX3CL1-dependent recruitment occurs only in some cancers. For example, a tumor produces a variety of chemokines that induce the recruitment of monocytes [176]. CX3CL1 is only one of them and often does not play a major role in the process.

Recruitment of monocytes to a tumor involving the CX3CL1-CX3CR1 axis is performed under strictly defined conditions (Figure 5). Three populations of monocytes in blood are distinguished: classical monocytes $\left(\mathrm{CD} 14^{++} \mathrm{CD} 16^{-}\right)$, intermediate monocytes $\left(\mathrm{CD} 14^{++} \mathrm{CD} 16^{+}\right)$and non-classical monocytes $\left(\mathrm{CD} 14^{+} \mathrm{CD} 16^{++}\right)[195,196]$. Classical monocytes have a low expression of CX3CR1, but high expressions of CC motif chemokine receptor (CCR)2 and CCR5. In turn, non-classical monocytes have high CX3CR1 expression and low CCR2 and CCR5 expression. Therefore, these two monocyte populations are recruited by different chemokines [197]. Compared to classical monocytes, non-classical monocytes under the influence of LPS produce more pro-inflammatory cytokines but lower levels of interleukins 10 (IL-10) and chemokines MCP-1/CCL2 and RANTES/CCL5 [195]. Additionally, after differentiation to monocyte-derived dendritic cells, non-classical monocytes activate $\mathrm{CD} 4^{+} \mathrm{T}$ cells more strongly (i.e., than those originating from classical monocytes) [198]. However, non-classical monocytes can be recruited to a tumor by CX3CL1, where they perform proangiogenic roles [18]. Although sCX3CL1 acts chemotactically on non-classical monocytes, CX3CR1 binds with both forms of CX3CL1, and so at a high concentration of sCX3CL1, adhesion of non-classical monocytes to mCX3CL1 is impaired [199]. However, sCX3CL1 increases adhesion to fibronectin and intracellular adhesion molecule-1 (ICAM-1) [200].

There is also a second mechanism preventing the recruitment of pro-angiogenic non-classical monocytes to zones with intensive inflammatory reactions. During these reactions, TNF- $\alpha$ is released by the non-classical monocytes, but this requires a proteolytic cleavage by TACE/ADAM17 [201], an enzyme that also mediates the shedding of $\mathrm{mCX} 3 \mathrm{CL} 1$, which prevents monocyte adhesion to this protein [202].

Another mechanism of the influence of SCX3CL1 on monocyte migration is by interference with the activity of other chemokines. Without the presence of sCX3CL1, MCP-1/CCL2 causes an increase in monocyte adhesion, during which an increase in CX3CR1 surface expression may occur, resulting in improved adhesion to mCX3CL1 [203]. However, sCX3CL1 antagonizes MCP-1/CCL2-dependent trans-endothelial migration and chemotaxis of classical monocytes [204]. It seems that such an interaction between these chemokines occurs only in monocytes. CX3CL1-dependent recruitment of NK cells is not disturbed by MCP-1/CCL2 [204]. 
High concentration of $\mathrm{SCX} 3 \mathrm{CL} 1$

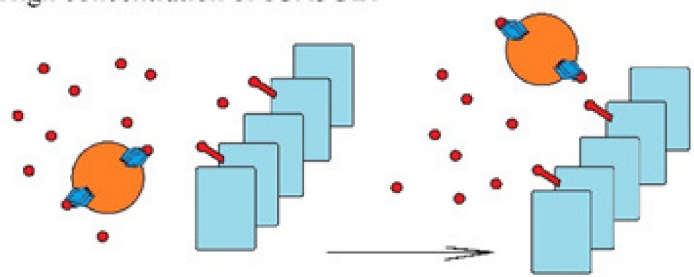

Low concentration of $\mathrm{SCX} 3 \mathrm{CL} 1$

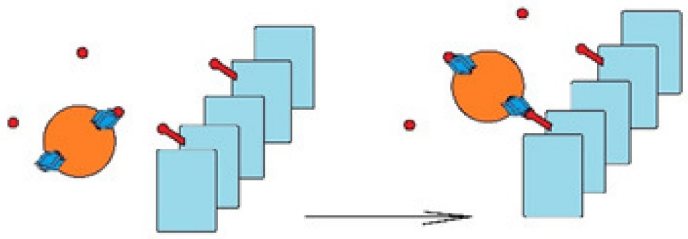

(a)
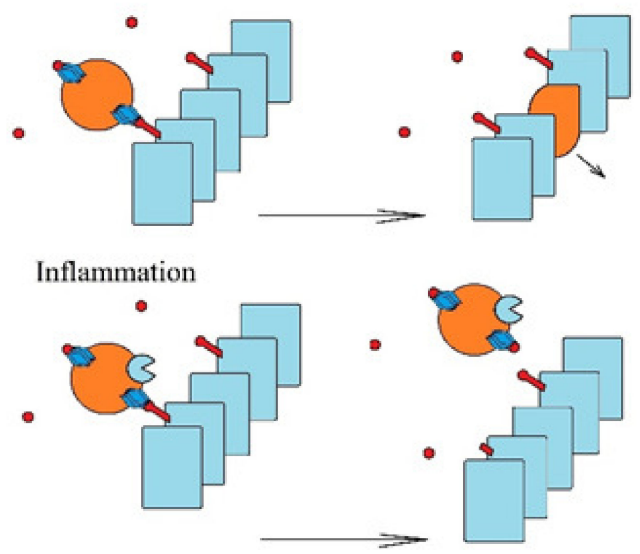

(c)

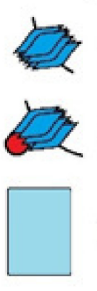

CX3CR1

CX3CR1 with CX3CL1

Endothelial cells
Low expression of $\mathrm{mCX} 3 \mathrm{Cl} .1$
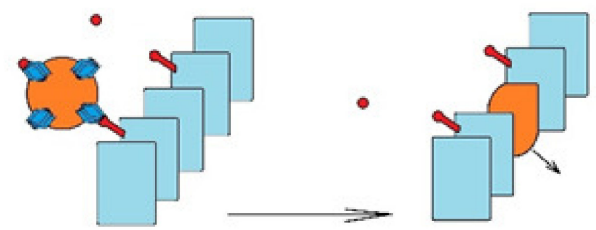

High expression of mCX3CL1
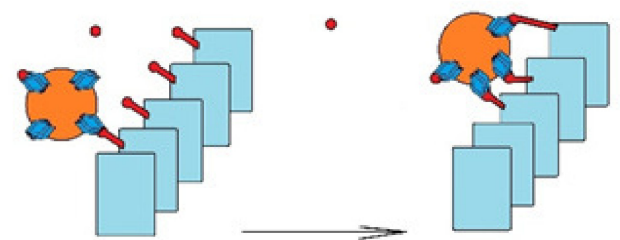

(b)

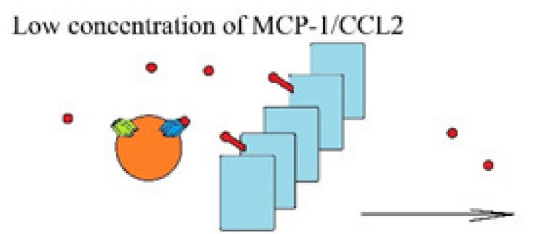

High concentration of MCP-1/CCL2
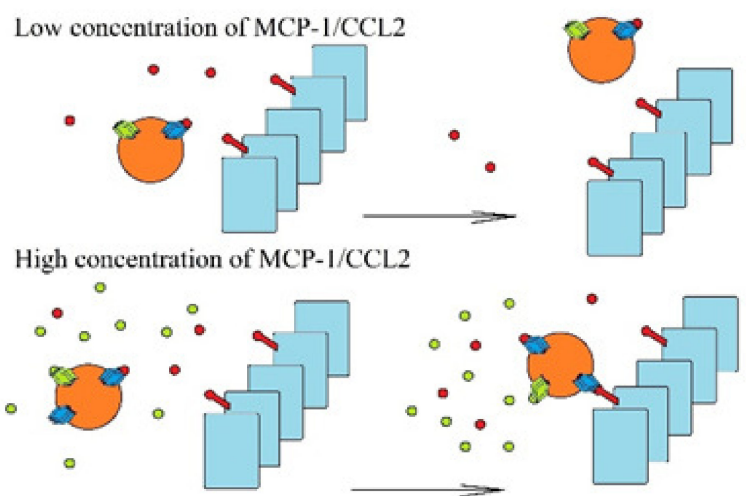

(d)

Figure 5. Recruitment of monocytes in various environments. Monocytes are recruited via mCX3CL1-dependent adhesion to vascular walls and transendothelial migration. These processes depend on: (a) the concentration of sCX3CL1. A high concentration of this chemokine activates all CX3CR1 and it can no longer bind more CX3CL1, including mCX3CL1. (b) Concentrations of mCX3CL1 on the vascular walls. A high concentration of mCX3CL1 causes very strong monocyte adhesion, which causes retention of these cells on the vascular walls and inhibit transendothelial migration of monocytes. (c) Inflammatory processes induced in recruited monocytes, in particular the level of TACE/ADAM17 activity. Inflammatory reactions increase the production of TNF- $\alpha$ and TACE/ADAM17 (an enzyme that releases this pro-inflammatory cytokine). However, this metalloproteinase also cleaves mCX3CL1. This results in the releases of sCX3CL1, and hence, reduces the amount of mCX3CL1 on the walls of the blood vessels. (d) Concentrations of other chemokines, in particular MCP-1/CCL2. Activation of MCP-1/CCL2 receptor (CCR2) causes increase CX3CR1-dependent monocyte adhesion.

Inflammatory reactions increase mCX3CL1 levels on endothelial cells [18,30-33]. This leads to the adhesion of non-classical monocytes to vessel walls near the tumor [18], followed by the production of IL-6, MCP-1/CCL2 and MMP-9 by monocytes [205]. However, the high levels of mCX3CL1 do not allow trans-endothelial migration of these monocytes, and thus, their retention occurs on the 
endothelium [197]. For trans-endothelial migration of the monocytes to occur, it is necessary to reduce the level of mCX3CL1 on the endothelial cells, which takes place in hypoxia [31] and under the influence of TGF- $\beta$ [54]. It seems that this process in the tumor involves VEGF-A [18], a growth factor causing GATA3 to attach to the CX3CL1 gene, and thus, reducing its expression. In this way, it enables the trans-endothelial migration of non-classical monocytes.

Monocytes in the tumor niche differentiate into TAM, which shows CX3CR1 expression. The activation of this receptor inhibits the apoptosis of TAM cells [188], which results in an increase in their number in the tumor niche where they act pro-angiogenically [183]. Among other things, these TAM secrete MMP-9 which supports angiogenesis [18]. Additionally, in the tumor niche it is possible that CX3CL1 increases the production of platelet-derived factor 4 (PF-4)/CXCL4 in macrophages [206]. PF-4/CXCL4 amplifies VEGF-mediated angiogenesis. However, the direct influence of CX3CL1 on the pro-angiogenic properties of macrophages still needs to be thoroughly investigated, because CX3CL1 has been shown to reduce the production of VEGF-A by the granulocyte-macrophage colony-stimulating factor (GM-CSF)-stimulated macrophages, but at the same time increase expression of anti-angiogenic thrombospondin 1 (THBS-1) and disintegrin, and metalloproteinase with a thrombospondin motif (ADAMTS-1) [207], which inhibits angiogenesis.

The CX3CL1-CX3CR1 axis also participates in cellular interactions in the tumor niche. In a tumor, TAM shows a high expression of CX3CR1 [191,208]. The production of CX3CL1 [147] by cancer cells enables TAM migration to the vicinity of these cells [209], followed by the cross-talk of TAM and cancer cells through intercellular signaling. IL-10 produced by macrophages induces CX3CR1 expression on lung cancer cells [185]. Additionally, I-309/CCL1, macrophage inflammatory protein $1 \alpha$ (MIP-1 $\alpha$ )/CCL3 and granulocyte colony-stimulating factor (G-CSF) from TAM increase CX3CL1 expression on lung cancer cells [185]. The increase in CX3CL1-CX3CR1 axis expression participates in migration, invasion, metastasis and angiogenesis of lung cancer [185].

The CX3CL1-CX3CR1 axis has important functions in the brain. CX3CR1 expression occurs in microglia [25-27], while nerve cells have CX3CL1 expression, which enables microglia chemotaxis to the nerve cells. A similar mechanism takes place between microglia and NF1-optic pathway gliomas [210]. In the GBM tumor, microglia group around the tumor mass and then infiltrate the tumor [211]. However, the recruitment of microglia to a GBM tumor does not depend on the CX3CL1-CX3CR1 axis [212,213], although one study on the polymorphism of the CX3CR1 gene showed that the CX3CL1-CX3CR1 axis is important for the recruitment of tumor tissue by microglia [214]. Significantly, CX3CL1 is not the only chemokine involved in this process, e.g., also important in the recruitment of microglia to GBM tumor are MCP-1/CCL2 [132] and RANTES/CCL5 [215].

The CX3CL1-CX3CR1 axis seems to work only locally. TAM and microglia show high expression of CX3CR1 [132,208,209], whereas high CX3CL1 expression occurs in other cells [209], e.g., in GBM cells [147], especially in cells with IDH1-R132H mutation of the gene encoding isocitrate dehydrogenase 1 (IDH1) [78]. This results in the phosphorylation of NF-KB and an increase in CX3CL1 expression. CX3CL1 expression enables the migration and adhesion of TAM and microglia to GBM cells [209], which increases the intercellular signaling between these cells, although at the same time it also causes the migration and accumulation of NK cells [78].

CX3CL1 reduces inflammatory reactions in macrophages [133,190] and microglia [213,216,217], although this effect may depend on the microenvironment, because in hypoxia, CX3CR1 is important for the activation of microglia [218]. The anti-inflammatory effect of CX3CL1 also depends on its concentration and type of cells. In macrophages, CX3CL1 at $0.9 \mathrm{ng} / \mathrm{mL}(0.03 \mathrm{nM})$ reduced inflammatory reactions [190] via a mechanism dependent on the increased level of anti-inflammatory prostaglandin 15-deoxy- $\Delta^{12,14}$-prostaglandin $\mathrm{J}_{2}\left(15 \mathrm{~d}-\mathrm{PGJ}_{2}\right)$ [219]. However, at $90 \mathrm{ng} / \mathrm{mL}(3 \mathrm{nM})$ in macrophages, CX3CL1 increased the level of interleukins 23 (IL-23), which offsets its anti-inflammatory effect [190]. The concentration of $90 \mathrm{ng} / \mathrm{mL}$ ( $3 \mathrm{nM}$ ) occurs in inflammatory reactions, and thus, the nature of the action of CX3CL1 on inflammatory reactions in macrophages in a tumor depends on the intensity 
of these reactions. In contrast, in microglia, CX3CL1 at $200 \mathrm{ng} / \mathrm{mL}(6 \mathrm{nM})$ had an anti-inflammatory effect [217].

The suppression of inflammatory reactions by CX3CL1 results in reduced production of IL-1 $\beta[213,216,217]$ and TNF- $\alpha[190,216]$, and increased expression of heme oxygenase 1 (HO-1) [133]. It has been reported that an increase in $\mathrm{HO}-1$ expression in gut macrophages protects against colorectal carcinogenesis [133]. Additionally, in GBM, a reduction in IL-1 $\beta$ expression by CX3CL1 has an anticancer effect [213] because IL-1 $\beta$ is important in GBM cell proliferation and migration [220].

\section{Impact on the Recruitment of Myeloid-Derived Suppressor Cells}

MDSC are responsible for tumor immune evasion in a tumor niche [221]. This heterogeneous group of cells includes monocytic myeloid-derived suppressor cells (Mo-MDSC) with high expression of CX3CR1 [222], which allows them to accumulate in a tumor with a high expression of SCX3CL1 [17]. Due to the expression of sCX3CL1 by a tumor, Mo-MDSC can migrate close to these cells and offset the effects of anticancer lymphocytes [147]. However, eotaxin-3/CCL26 is a chemokine that, in addition to activating its CCR3 receptor [135,223], can also activate CX3CR1 [224]. For this reason, Mo-MDSC may also be recruited by the eotaxin-3/CCL26 $\rightarrow$ CX3CR1 axis [225].

Mo-MDSC recruitment by the two chemokines takes place mainly during hypoxia, when the expression of eotaxin-3/CCL26 [225] and CX3CL1 [8,52] increases in cancer cells. In the tumor, Mo-MDSC participates in tumor immune evasion, causing T cell anergy by producing NO [226]. Mo-MDSC also

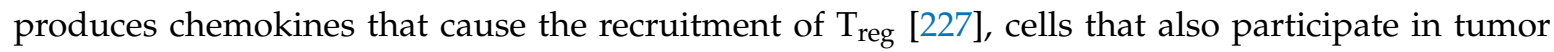
immune evasion [228]. Mo-MDSC also has a high expression of MMP-9, an enzyme that supports migration, invasion and angiogenesis in the tumor [225].

\section{The Importance of CX3CL1 in Cancer Processes Involving HCMV}

In many types of tumors, increased expression of CX3CL1 causes an increased immune response against these tumors, and thus, a better prognosis for the patient $[73,79,81]$. However, some cancers show the opposite correlation. For example, increased expression of CX3CL1 gives a poorer prognosis in grade III-IV brain tumors [110]. One of the possible causes is the effect of CX3CL1 on the human cytomegalovirus (HCMV), because this chemokine plays an important role in the development cycle of this virus, which in turn may have an important function in GBM. However, the connection between HCMV and GBM is a highly contentious issue. Some researchers have shown that the genetic material of the virus and its antigens are present in the GBM tumor [229-231]. It has also been confirmed that HCMV theoretically intensifies cancer processes $[232,233]$. For this reason, immunotherapy against HCMV antigens [234] or antiviral drugs [235] give good results in GBM treatment. On the other hand, some researchers have demonstrated no active HCMV infection in the GBM tumor [236,237].

HCMV occurs in about $60 \%$ of the population $[238,239]$. In people with a normally functioning immune system, HCMV infection is almost always asymptomatic and leads to a latent infection of some cells. HCMV causes latent infection of CD34 ${ }^{+}$hematopoietic progenitor cells [240,241], which become the reservoir of this virus, passing it to daughter cells, including monocytes. However, HCMV is unable to replicate itself in these cells [242], and thus, the monocyte infection is latent. In these cells, the virus is spread throughout the body [243]. An important element of the latent infection is the expression of US28 [240,244,245], a protein also important for the migration of infected monocytes. US28 is a non-specific chemokine receptor [246] associated with CX3CL1 [247]. The activation of US28 by CX3CL1 increases the migration of infected cells [246] and this effect is greater than the activation of CX3CR1 by CX3CL1 [248]. Due to this, US28 participates in the adhesion of latent infected monocytes, transport of these cells through the vessel walls, and their recruitment to sites with a high expression of mCX3CL1 $[249,250]$. One such site is a tumor, a place of intensive immunological reactions and high expression of CX3CL1. This environment with immunological defects is convenient for the active replication of the virus. US28 may also be involved in cell infection [251], e.g., by chemotaxis of infected 
cells to cells showing SCX3CL1 expression. However, these processes are very difficult to study because US28 is only found in the human strains of cytomegalovirus [249].

\section{Conclusions: The Application of CX3CL1 in Cancer Therapy}

An increased expression of CX3CL1 in a cancer cell leads to the infiltration of NK cells, dendritic cells, $\mathrm{CD}^{+}$and $\mathrm{CD} 8^{+} \mathrm{T}$ cells into the tumor $[61,63,69-78]$. This, in turn, leads to an increase in the anti-tumor immune response, which reduces the rate of tumor growth and increases the survival of experimental animals and cancer patients. Therefore, gene therapy with the use of the adenoviral vector [61], plasmid vector or DNA vaccine [72,252,253] with the CX3CL1 gene that increases the expression of CX3CL1 in the tumor has a therapeutic effect. In addition, it is postulated to simultaneously increase the expression of CX3CL1 and other cytokines that enhance the immune response, e.g., IL-2, which significantly increases the effect of CX3CL1 in a tumor [252]. Additionally, increased expression of CX3CR1 ex vivo in T cells achieved by the use of the retrovirus vector, and introducing these cells into the body of mice has led to an increase in the homing of these cells to a colorectal tumor [254], which was associated with a high CX3CL1 expression in the tumor and had an anti-tumor effect. Another study showed that the use of ex vivo adenovirus vector in increasing CX3CL1 expression in dendritic cells and introducing these cells into a tumor increased the anti-tumor response [255], in particular the homing of $\mathrm{CD} 8^{+} \mathrm{T}$ cells and $\mathrm{CD} 4^{+} \mathrm{T}$ cells to the tumor.

However, therapy with this chemokine alone will be ineffective due to the numerous processes in a tumor, which results in cancer immune evasion [256]. In addition, some cancers enhance the pro-cancer properties of CX3CL1. Currently, it is postulated that immunotherapy should be combined with drugs that suppress the immunosuppressive mechanisms in a tumor [257]. As such, CX3CL1 may be used as one of the elements of immunotherapy, an adjuvant increasing the effectiveness of anticancer therapy.

Author Contributions: J.K.: writing-original draft preparation; D.S.: investigation; K.K.: investigation; S.G.: investigation; I.G.: investigation; D.C.: Funding acquisition; I.B.-B.: Writing-review and editing. All authors have read and agreed to the published version of the manuscript.

Funding: This study was supported by the statutory budget of the Department of Biochemistry and Medical Chemistry Pomeranian Medical University in Szczecin, Poland.

Conflicts of Interest: The authors declare no conflicts of interest.

\section{Abbreviations}

$\begin{array}{ll}\text { ADAM10 } & \text { A disintegrin and metalloproteinase } 10 \\ \text { CAF } & \text { Cancer-associated fibroblasts } \\ \text { CCL } & \text { CC motif chemokine ligand } \\ \text { CCR } & \text { CC motif chemokine receptor } \\ \text { CX3CL1 } & \text { CX3C chemokine ligand 1 } \\ \text { CX3CR1 } & \text { CX3C chemokine receptor } 1 \\ \text { CXCL } & \text { CXC motif chemokine ligand } \\ \text { EGFR } & \text { Epidermal growth factor receptor } \\ \text { EMT } & \text { Epithelial-to-mesenchymal transition } \\ \text { ERK } & \text { Extracellular signal-regulated kinase } \\ \text { FAK } & \text { Focal adhesion kinase } \\ \text { GBM } & \text { Glioblastoma multiforme } \\ \text { HCMV } & \text { Human cytomegalovirus } \\ \text { HIF- } 1 \alpha & \text { Hypoxia inducible factor-1 } \alpha \\ \text { IFN- } \gamma & \text { Interferon- } \gamma \\ \text { IL-1 } \beta & \text { Interleukin } 1 \beta \\ \text { MAPK } & \text { Mitogen-activated protein kinase }\end{array}$




$\begin{array}{ll}\text { mCX3CL1 } & \text { Membrane attached form of CX3CL1 } \\ \text { MMP } & \text { Matrix metalloproteinase } \\ \text { NF- } \kappa \text { B } & \text { Nuclear factor } \kappa \text { B } \\ \text { PI3K } & \text { Phosphatidylinositol-4,5-bisphosphate 3-kinase } \\ \text { sCX3CL1 } & \text { Soluble form of CX3CL1 } \\ \text { Sp1 } & \text { Specificity protein } 1 \\ \text { TACE/ADAM17 } & \text { Tumor necrosis factor- } \alpha \text { converting enzyme/a disintegrin and metalloproteinase } 17 \\ \text { TAM } & \text { Tumor-associated macrophages } \\ \text { TGF- } \beta & \text { Transforming growth factor } \beta \\ \text { TNF- } \alpha & \text { Tumor necrosis factor } \alpha \\ \text { T }_{\text {reg }} & \text { Regulatory T cells } \\ \text { VEGF } & \text { Vascular endothelial growth factor }\end{array}$

\section{References}

1. Bray, F.; Ferlay, J.; Soerjomataram, I.; Siegel, R.L.; Torre, L.A.; Jemal, A. Global cancer statistics 2018: Globocan estimates of incidence and mortality worldwide for 36 cancers in 185 countries. CA Cancer J. Clin. 2018, 68, 394-424. [CrossRef] [PubMed]

2. Hanahan, D.; Weinberg, R.A. The hallmarks of cancer. Cell 2000, 100, 57-70. [CrossRef]

3. Egeblad, M.; Nakasone, E.S.; Werb, Z. Tumors as organs: Complex tissues that interface with the entire organism. Dev. Cell 2010, 18, 884-901. [CrossRef] [PubMed]

4. Hanahan, D.; Weinberg, R.A. Hallmarks of cancer: The next generation. Cell 2011, 144, 646-674. [CrossRef]

5. Mantovani, A.; Savino, B.; Locati, M.; Zammataro, L.; Allavena, P.; Bonecchi, R. The chemokine system in cancer biology and therapy. Cytokine Growth Factor Rev. 2010, 21, 27-39. [CrossRef]

6. Kim, M.; Rooper, L.; Xie, J.; Kajdacsy-Balla, A.A.; Barbolina, M.V. Fractalkine receptor CX(3)CR1 is expressed in epithelial ovarian carcinoma cells and required for motility and adhesion to peritoneal mesothelial cells. Mol. Cancer Res. 2012, 10, 11-24. [CrossRef]

7. Tardáguila, M.; Mira, E.; García-Cabezas, M.A.; Feijoo, A.M.; Quintela-Fandino, M.; Azcoitia, I.; Lira, S.A.; Mañes, S. CX3CL1 promotes breast cancer via transactivation of the EGF pathway. Cancer Res. 2013, 73, 4461-4473. [CrossRef]

8. Tang, J.; Chen, Y.; Cui, R.; Li, D.; Xiao, L.; Lin, P.; Du, Y.; Sun, H.; Yu, X.; Zheng, X. Upregulation of fractalkine contributes to the proliferative response of prostate cancer cells to hypoxia via promoting the G1/S phase transition. Mol. Med. Rep. 2015, 12, 7907-7914. [CrossRef]

9. Lee, S.J.; Namkoong, S.; Kim, Y.M.; Kim, C.K.; Lee, H.; Ha, K.S.; Chung, H.T.; Kwon, Y.G.; Kim, Y.M. Fractalkine stimulates angiogenesis by activating the Raf-1/MEK/ERK- and PI3K/Akt/eNOS-dependent signal pathways. Am. J. Physiol. Heart Circ. Physiol. 2006, 291, H2836-H2846. [CrossRef]

10. Ryu, J.; Lee, C.W.; Hong, K.H.; Shin, J.A.; Lim, S.H.; Park, C.S.; Shim, J.; Nam, K.B.; Choi, K.J.; Kim, Y.H.; et al. Activation of fractalkine/CX3CR1 by vascular endothelial cells induces angiogenesis through VEGF-A/KDR and reverses hindlimb ischaemia. Cardiovasc. Res. 2008, 78, 333-340. [CrossRef]

11. Volin, M.V.; Huynh, N.; Klosowska, K.; Reyes, R.D.; Woods, J.M. Fractalkine-induced endothelial cell migration requires MAP kinase signaling. Pathobiology 2010, 77, 7-16. [CrossRef] [PubMed]

12. Wang, H.; Cai, J.; Du, S.; Guo, Z.; Xin, B.; Wang, J.; Wei, W.; Shen, X. Fractalkine/CX3CR1 induces apoptosis resistance and proliferation through the activation of the AKT/NF- $\mathrm{kB}$ cascade in pancreatic cancer cells. Cell Biochem. Funct. 2017, 35, 315-326. [CrossRef] [PubMed]

13. Marchesi, F.; Piemonti, L.; Fedele, G.; Destro, A.; Roncalli, M.; Albarello, L.; Doglioni, C.; Anselmo, A.; Doni, A.; Bianchi, P.; et al. The chemokine receptor CX3CR1 is involved in the neural tropism and malignant behavior of pancreatic ductal adenocarcinoma. Cancer Res. 2008, 68, 9060-9069. [CrossRef] [PubMed]

14. Liang, Y.; Yi, L.; Liu, P.; Jiang, L.; Wang, H.; Hu, A.; Sun, C.; Dong, J. CX3CL1 involves in breast cancer metastasizing to the spine via the Src/FAK signaling pathway. J. Cancer 2018, 9, 3603-3612. [CrossRef]

15. Liu, P.; Liang, Y.; Jiang, L.; Wang, H.; Wang, S.; Dong, J. CX3CL1/fractalkine enhances prostate cancer spinal metastasis by activating the Src/FAK pathway. Int. J. Oncol. 2018, 53, 1544-1556. [CrossRef]

16. Liu, W.; Liang, Y.; Chan, Q.; Jiang, L.; Dong, J. CX3CL1 promotes lung cancer cell migration and invasion via the Src/focal adhesion kinase signaling pathway. Oncol. Rep. 2019, 41, 1911-1917. [CrossRef] 
17. Okuma, A.; Hanyu, A.; Watanabe, S.; Hara, E. p16Ink4a and p21Cip1/Waf1 promote tumour growth by enhancing myeloid-derived suppressor cells chemotaxis. Nat. Commun. 2017, 8, 1-13. [CrossRef]

18. Sidibe, A.; Ropraz, P.; Jemelin, S.; Emre, Y.; Poittevin, M.; Pocard, M.; Bradfield, P.F.; Imhof, B.A. Angiogenic factor-driven inflammation promotes extravasation of human proangiogenic monocytes to tumours. Nat. Commun. 2018, 9, 1-19. [CrossRef]

19. Jamieson, W.L.; Shimizu, S.; D'Ambrosio, J.A.; Meucci, O.; Fatatis, A. CX3CR1 is expressed by prostate epithelial cells and androgens regulate the levels of CX3CL1/fractalkine in the bone marrow: Potential role in prostate cancer bone tropism. Cancer Res. 2008, 68, 1715-1722. [CrossRef]

20. Celesti, G.; Di Caro, G.; Bianchi, P.; Grizzi, F.; Marchesi, F.; Basso, G.; Rahal, D.; Delconte, G.; Catalano, M.; Cappello, P.; et al. Early expression of the fractalkine receptor CX3CR1 in pancreatic carcinogenesis. Br. J. Cancer 2013, 109, 2424-2433. [CrossRef]

21. Gurler Main, H.; Xie, J.; Muralidhar, G.G.; Elfituri, O.; Xu, H.; Kajdacsy-Balla, A.A.; Barbolina, M.V. Emergent role of the fractalkine axis in dissemination of peritoneal metastasis from epithelial ovarian carcinoma. Oncogene 2017, 36, 3025-3036. [CrossRef] [PubMed]

22. Bazan, J.F.; Bacon, K.B.; Hardiman, G.; Wang, W.; Soo, K.; Rossi, D.; Greaves, D.R.; Zlotnik, A.; Schall, T.J. A new class of membrane-bound chemokine with a CX3C motif. Nature 1997, 385, 640-644. [CrossRef] [PubMed]

23. Pan, Y.; Lloyd, C.; Zhou, H.; Dolich, S.; Deeds, J.; Gonzalo, J.A.; Vath, J.; Gosselin, M.; Ma, J.; Dussault, B.; et al. Neurotactin, a membrane-anchored chemokine upregulated in brain inflammation. Nature 1997, 387, 611-617. [CrossRef] [PubMed]

24. Imai, T.; Hieshima, K.; Haskell, C.; Baba, M.; Nagira, M.; Nishimura, M.; Kakizaki, M.; Takagi, S.; Nomiyama, H.; Schall, T.J.; et al. Identification and molecular characterization of fractalkine receptor CX3CR1, which mediates both leukocyte migration and adhesion. Cell 1997, 91, 521-530. [CrossRef]

25. Maciejewski-Lenoir, D.; Chen, S.; Feng, L.; Maki, R.; Bacon, K.B. Characterization of fractalkine in rat brain cells: Migratory and activation signals for CX3CR-1-expressing microglia. J. Immunol. 1999, 163, 1628-1635.

26. Jung, S.; Aliberti, J.; Graemmel, P.; Sunshine, M.J.; Kreutzberg, G.W.; Sher, A.; Littman, D.R. Analysis of fractalkine receptor $\mathrm{CX}(3) \mathrm{CR} 1$ function by targeted deletion and green fluorescent protein reporter gene insertion. Mol. Cell Biol. 2000, 20, 4106-4114. [CrossRef]

27. Zujovic, V.; Benavides, J.; Vigé, X.; Carter, C.; Taupin, V. Fractalkine modulates TNF-alpha secretion and neurotoxicity induced by microglial activation. Glia 2000, 29, 305-315. [CrossRef]

28. Noda, M.; Doi, Y.; Liang, J.; Kawanokuchi, J.; Sonobe, Y.; Takeuchi, H.; Mizuno, T.; Suzumura, A. Fractalkine attenuates excito-neurotoxicity via microglial clearance of damaged neurons and antioxidant enzyme heme oxygenase-1 expression. J. Biol. Chem. 2011, 286, 2308-2319. [CrossRef]

29. Rossi, D.L.; Hardiman, G.; Copeland, N.G.; Gilbert, D.J.; Jenkins, N.; Zlotnik, A.; Bazan, J.F. Cloning and characterization of a new type of mouse chemokine. Genomics 1998, 47, 163-170. [CrossRef]

30. Garcia, G.E.; Xia, Y.; Chen, S.; Wang, Y.; Ye, R.D.; Harrison, J.K.; Bacon, K.B.; Zerwes, H.G.; Feng, L. NF-kappaB-dependent fractalkine induction in rat aortic endothelial cells stimulated by IL-1beta, TNF-alpha, and LPS. J. Leukoc. Biol. 2000, 67, 577-584. [CrossRef]

31. Yamashita, K.; Imaizumi, T.; Hatakeyama, M.; Tamo, W.; Kimura, D.; Kumagai, M.; Yoshida, H.; Satoh, K. Effect of hypoxia on the expression of fractalkine in human endothelial cells. Tohoku J. Exp. Med. 2003, 200, 187-194. [CrossRef] [PubMed]

32. Ahn, S.Y.; Cho, C.H.; Park, K.G.; Lee, H.J.; Lee, S.; Park, S.K.; Lee, I.K.; Koh, G.Y. Tumor necrosis factor-alpha induces fractalkine expression preferentially in arterial endothelial cells and mithramycin A suppresses TNF-alpha-induced fractalkine expression. Am. J. Pathol. 2004, 164, 1663-1672. [CrossRef]

33. Matsumiya, T.; Ota, K.; Imaizumi, T.; Yoshida, H.; Kimura, H.; Satoh, K. Characterization of synergistic induction of CX3CL1/fractalkine by TNF-alpha and IFN-gamma in vascular endothelial cells: An essential role for TNF-alpha in post-transcriptional regulation of CX3CL1. J. Immunol. 2010, 184, 4205-4214. [CrossRef] [PubMed]

34. Garton, K.J.; Gough, P.J.; Blobel, C.P.; Murphy, G.; Greaves, D.R.; Dempsey, P.J.; Raines, E.W. Tumor necrosis factor-alpha-converting enzyme (ADAM17) mediates the cleavage and shedding of fractalkine (CX3CL1). J. Biol. Chem. 2001, 276, 37993-38001. [PubMed] 
35. Fong, A.M.; Erickson, H.P.; Zachariah, J.P.; Poon, S.; Schamberg, N.J.; Imai, T.; Patel, D.D. Ultrastructure and function of the fractalkine mucin domain in CX(3)C chemokine domain presentation. J. Biol. Chem. 2000, 275, 3781-3786. [CrossRef]

36. Haskell, C.A.; Cleary, M.D.; Charo, I.F. Molecular uncoupling of fractalkine-mediated cell adhesion and signal transduction. Rapid flow arrest of CX3CR1-expressing cells is independent of G-protein activation. J. Biol. Chem. 1999, 274, 10053-10058. [CrossRef]

37. Fong, A.M.; Robinson, L.A.; Steeber, D.A.; Tedder, T.F.; Yoshie, O.; Imai, T.; Patel, D.D. Fractalkine and CX3CR1 mediate a novel mechanism of leukocyte capture, firm adhesion, and activation under physiologic flow. J. Exp. Med. 1998, 188, 1413-1419. [CrossRef]

38. Clark, A.K.; Yip, P.K.; Grist, J.; Gentry, C.; Staniland, A.A.; Marchand, F.; Dehvari, M.; Wotherspoon, G.; Winter, J.; Ullah, J.; et al. Inhibition of spinal microglial cathepsin $\mathrm{S}$ for the reversal of neuropathic pain. Proc. Natl. Acad. Sci. USA 2007, 104, 10655-10660. [CrossRef]

39. Bourd-Boittin, K.; Basset, L.; Bonnier, D.; L’helgoualc’h, A.; Samson, M.; Théret, N. CX3CL1/fractalkine shedding by human hepatic stellate cells: Contribution to chronic inflammation in the liver. J. Cell Mol. Med. 2009, 13, 1526-1535. [CrossRef]

40. Hundhausen, C.; Misztela, D.; Berkhout, T.A.; Broadway, N.; Saftig, P.; Reiss, K.; Hartmann, D.; Fahrenholz, F.; Postina, R.; Matthews, V.; et al. The disintegrin-like metalloproteinase ADAM10 is involved in constitutive cleavage of CX3CL1 (fractalkine) and regulates CX3CL1-mediated cell-cell adhesion. Blood 2003, 102, 1186-1195. [CrossRef]

41. Hurst, L.A.; Bunning, R.A.; Sharrack, B.; Woodroofe, M.N. siRNA knockdown of ADAM-10, but not ADAM-17, significantly reduces fractalkine shedding following pro-inflammatory cytokine treatment in a human adult brain endothelial cell line. Neurosci. Lett. 2012, 521, 52-56. [CrossRef] [PubMed]

42. Tsou, C.L.; Haskell, C.A.; Charo, I.F. Tumor necrosis factor-alpha-converting enzyme mediates the inducible cleavage of fractalkine. J. Biol. Chem. 2001, 276, 44622-44626. [CrossRef] [PubMed]

43. Jones, B.A.; Riegsecker, S.; Rahman, A.; Beamer, M.; Aboualaiwi, W.; Khuder, S.A.; Ahmed, S. Role of ADAM-17, p38 MAPK, cathepsins, and the proteasome pathway in the synthesis and shedding of fractalkine/CX 3 CL1 in rheumatoid arthritis. Arthritis Rheum 2013, 65, 2814-2825. [CrossRef] [PubMed]

44. O'Sullivan, S.A.; Gasparini, F.; Mir, A.K.; Dev, K.K. Fractalkine shedding is mediated by p38 and the ADAM10 protease under pro-inflammatory conditions in human astrocytes. J. Neuroinflamm. 2016, 13, 189. [CrossRef] [PubMed]

45. Combadiere, C.; Salzwedel, K.; Smith, E.D.; Tiffany, H.L.; Berger, E.A.; Murphy, P.M. Identification of CX3CR1. A chemotactic receptor for the human CX3C chemokine fractalkine and a fusion coreceptor for HIV-1. J. Biol. Chem. 1998, 273, 23799-23804. [CrossRef] [PubMed]

46. Yao, X.; Qi, L.; Chen, X.; Du, J.; Zhang, Z.; Liu, S. Expression of CX3CR1 associates with cellular migration, metastasis, and prognosis in human clear cell renal cell carcinoma. Urol. Oncol. 2014, 32, 162-170. [CrossRef]

47. Shulby, S.A.; Dolloff, N.G.; Stearns, M.E.; Meucci, O.; Fatatis, A. CX3CR1-fractalkine expression regulates cellular mechanisms involved in adhesion, migration, and survival of human prostate cancer cells. Cancer Res. 2004, 64, 4693-4698. [CrossRef]

48. Huang, L.; Ma, B.; Ma, J.; Wang, F. Fractalkine/CX3CR1 axis modulated the development of pancreatic ductal adenocarcinoma via JAK/STAT signaling pathway. Biochem. Biophys. Res. Commun. 2017, 493, 1510-1517. [CrossRef]

49. Chandrasekar, B.; Mummidi, S.; Perla, R.P.; Bysani, S.; Dulin, N.O.; Liu, F.; Melby, P.C. Fractalkine (CX3CL1) stimulated by nuclear factor kappaB (NF-kappaB)-dependent inflammatory signals induces aortic smooth muscle cell proliferation through an autocrine pathway. Biochem. J. 2003, 373, 547-558. [CrossRef]

50. White, G.E.; Tan, T.C.; John, A.E.; Whatling, C.; McPheat, W.L.; Greaves, D.R. Fractalkine has anti-apoptotic and proliferative effects on human vascular smooth muscle cells via epidermal growth factor receptor signalling. Cardiovasc. Res. 2010, 85, 825-835. [CrossRef]

51. Huang, Q.; Li, S.; Zhang, L.; Qiao, X.; Zhang, Y.; Zhao, X.; Xiao, G.; Li, Z. CAPE-pNO 2 Inhibited the Growth and Metastasis of Triple-Negative Breast Cancer via the EGFR/STAT3/Akt/E-Cadherin Signaling Pathway. Front. Oncol. 2019, 9, 461. [CrossRef] [PubMed] 
52. Tang, J.; Xiao, L.; Cui, R.; Li, D.; Zheng, X.; Zhu, L.; Sun, H.; Pan, Y.; Du, Y.; Yu, X. CX3CL1 increases invasiveness and metastasis by promoting epithelial-to-mesenchymal transition through the TACE/TGF- $\alpha /$ EGFR pathway in hypoxic androgen-independent prostate cancer cells. Oncol. Rep. 2016, 35, 1153-1162. [CrossRef] [PubMed]

53. Zunke, F.; Rose-John, S. The shedding protease ADAM17: Physiology and pathophysiology. Biochim. Biophys. Acta Mol. Cell Res. 2017, 1864, 2059-2070. [CrossRef] [PubMed]

54. Sukkar, M.B.; Issa, R.; Xie, S.; Oltmanns, U.; Newton, R.; Chung, K.F. Fractalkine/CX3CL1 production by human airway smooth muscle cells: Induction by IFN-gamma and TNF-alpha and regulation by TGF-beta and corticosteroids. Am. J. Physiol. Lung Cell Mol. Physiol. 2004, 287, L1230-L1240. [CrossRef]

55. Shiraishi, K.; Fukuda, S.; Mori, T.; Matsuda, K.; Yamaguchi, T.; Tanikawa, C.; Ogawa, M.; Nakamura, Y.; Arakawa, H. Identification of fractalkine, a CX3C-type chemokine, as a direct target of p53. Cancer Res. 2000, $60,3722-3726$.

56. Hess, S.; Methe, H.; Kim, J.O.; Edelman, E.R. NF-kappaB activity in endothelial cells is modulated by cell substratum interactions and influences chemokine-mediated adhesion of natural killer cells. Cell Transplant. 2009, 18, 261-273. [CrossRef]

57. Johnson, L.A.; Jackson, D.G. The chemokine CX3CL1 promotes trafficking of dendritic cells through inflamed lymphatics. J. Cell Sci. 2013, 126, 5259-5270. [CrossRef]

58. Hertwig, L.; Hamann, I.; Romero-Suarez, S.; Millward, J.M.; Pietrek, R.; Chanvillard, C.; Stuis, H.; Pollok, K.; Ransohoff, R.M.; Cardona, A.E.; et al. CX3CR1-dependent recruitment of mature NK cells into the central nervous system contributes to control autoimmune neuroinflammation. Eur. J. Immunol. 2016, 46, 1984-1996. [CrossRef]

59. Dichmann, S.; Herouy, Y.; Purlis, D.; Rheinen, H.; Gebicke-Härter, P.; Norgauer, J. Fractalkine induces chemotaxis and actin polymerization in human dendritic cells. Inflamm. Res. 2001, 50, 529-533. [CrossRef]

60. Foussat, A.; Coulomb-L'Hermine, A.; Gosling, J.; Krzysiek, R.; Durand-Gasselin, I.; Schall, T.; Balian, A.; Richard, Y.; Galanaud, P.; Emilie, D. Fractalkine receptor expression by T lymphocyte subpopulations and in vivo production of fractalkine in human. Eur. J. Immunol. 2000, 30, 87-97. [CrossRef]

61. Xin, H.; Kikuchi, T.; Andarini, S.; Ohkouchi, S.; Suzuki, T.; Nukiwa, T.; Huqun; Hagiwara, K.; Honjo, T.; Saijo, Y. Antitumor immune response by CX3CL1 fractalkine gene transfer depends on both NK and T cells. Eur. J. Immunol. 2005, 35, 1371-1380. [CrossRef] [PubMed]

62. Yan, Y.; Cao, S.; Liu, X.; Harrington, S.M.; Bindeman, W.E.; Adjei, A.A.; Jang, J.S.; Jen, J.; Li, Y.; Chanana, P.; et al. CX3CR1 identifies PD-1 therapy-responsive CD8+ T cells that withstand chemotherapy during cancer chemoimmunotherapy. JCI Insight 2018, 3. [CrossRef] [PubMed]

63. Yamauchi, T.; Hoki, T.; Oba, T.; Saito, H.; Attwood, K.; Sabel, M.S.; Chang, A.E.; Odunsi, K.; Ito, F. CX3CR1-CD8+ $\mathrm{T}$ cells are critical in antitumor efficacy but functionally suppressed in the tumor microenvironment. JCI Insight 2020, 5. [CrossRef] [PubMed]

64. Guo, J.; Zhang, M.; Wang, B.; Yuan, Z.; Guo, Z.; Chen, T.; Yu, Y.; Qin, Z.; Cao, X. Fractalkine transgene induces T-cell-dependent antitumor immunity through chemoattraction and activation of dendritic cells. Int. J. Cancer 2003, 103, 212-220. [CrossRef] [PubMed]

65. Pallandre, J.R.; Krzewski, K.; Bedel, R.; Ryffel, B.; Caignard, A.; Rohrlich, P.S.; Pivot, X.; Tiberghien, P.; Zitvogel, L.; Strominger, J.L.; et al. Dendritic cell and natural killer cell cross-talk: a pivotal role of CX3CL1 in NK cytoskeleton organization and activation. Blood 2008, 112, 4420-4424. [CrossRef] [PubMed]

66. Robinson, L.A.; Nataraj, C.; Thomas, D.W.; Cosby, J.M.; Griffiths, R.; Bautch, V.L.; Patel, D.D.; Coffman, T.M. The chemokine CX3CL1 regulates NK cell activity in vivo. Cell Immunol. 2003, 225, 122-130. [CrossRef]

67. Zhang, X.; Wei, H.; Wang, H.; Tian, Z. Involvement of interaction between Fractalkine and CX3CR1 in cytotoxicity of natural killer cells against tumor cells. Oncol. Rep. 2006, 15, 485-488. [CrossRef]

68. Yu, Y.R.; Fong, A.M.; Combadiere, C.; Gao, J.L.; Murphy, P.M.; Patel, D.D. Defective antitumor responses in CX3CR1-deficient mice. Int. J. Cancer 2007, 121, 316-322. [CrossRef]

69. Guo, J.; Chen, T.; Wang, B.; Zhang, M.; An, H.; Guo, Z.; Yu, Y.; Qin, Z.; Cao, X. Chemoattraction, adhesion and activation of natural killer cells are involved in the antitumor immune response induced by fractalkine/CX3CL1. Immunol. Lett. 2003, 89, 1-7. [CrossRef]

70. Lavergne, E.; Combadière, B.; Bonduelle, O.; Iga, M.; Gao, J.L.; Maho, M.; Boissonnas, A.; Murphy, P.M.; Debré, P.; Combadière, C. Fractalkine mediates natural killer-dependent antitumor responses in vivo. Cancer Res. 2003, 63, 7468-7474. 
71. Ohta, M.; Tanaka, F.; Yamaguchi, H.; Sadanaga, N.; Inoue, H.; Mori, M. The high expression of Fractalkine results in a better prognosis for colorectal cancer patients. Int. J. Oncol. 2005, 26, 41-47. [CrossRef] [PubMed]

72. Tang, L.; Hu, H.D.; Hu, P.; Lan, Y.H.; Peng, M.L.; Chen, M.; Ren, H. Gene therapy with CX3CL1/Fractalkine induces antitumor immunity to regress effectively mouse hepatocellular carcinoma. Gene Ther. 2007, 14, 1226-1234. [CrossRef] [PubMed]

73. Hyakudomi, M.; Matsubara, T.; Hyakudomi, R.; Yamamoto, T.; Kinugasa, S.; Yamanoi, A.; Maruyama, R.; Tanaka, T. Increased expression of fractalkine is correlated with a better prognosis and an increased number of both CD8+ T cells and natural killer cells in gastric adenocarcinoma. Ann. Surg. Oncol. 2008, 15, 1775-1782. [CrossRef] [PubMed]

74. Park, M.H.; Lee, J.S.; Yoon, J.H. High expression of CX3CL1 by tumor cells correlates with a good prognosis and increased tumor-infiltrating CD8+ T cells, natural killer cells, and dendritic cells in breast carcinoma. J. Surg. Oncol. 2012, 106, 386-392. [CrossRef]

75. Gillard-Bocquet, M.; Caer, C.; Cagnard, N.; Crozet, L.; Perez, M.; Fridman, W.H.; Sautès-Fridman, C.; Cremer, I. Lung tumor microenvironment induces specific gene expression signature in intratumoral NK cells. Front. Immunol. 2013, 4, 19. [CrossRef]

76. Tsang, J.Y.; Ni, Y.B.; Chan, S.K.; Shao, M.M.; Kwok, Y.K.; Chan, K.W.; Tan, P.H.; Tse, G.M. CX3CL1 expression is associated with poor outcome in breast cancer patients. Breast Cancer Res. Treat. 2013, 140, 495-504. [CrossRef]

77. Geismann, C.; Erhart, W.; Grohmann, F.; Schreiber, S.; Schneider, G.; Schäfer, H.; Arlt, A. TRAIL/NF-kB/CX3CL1 Mediated Onco-Immuno Crosstalk Leading to TRAIL Resistance of Pancreatic Cancer Cell Lines. Int. J. Mol. Sci. 2018, 19, 1661. [CrossRef]

78. Ren, F.; Zhao, Q.; Huang, L.; Zheng, Y.; Li, L.; He, Q.; Zhang, C.; Li, F.; Maimela, N.R.; Sun, Z.; et al. The R132H mutation in IDH1 promotes the recruitment of NK cells through CX3CL1/CX3CR1 chemotaxis and is correlated with a better prognosis in gliomas. Immunol. Cell Biol. 2019, 97, 457-469. [CrossRef]

79. Erreni, M.; Siddiqui, I.; Marelli, G.; Grizzi, F.; Bianchi, P.; Morone, D.; Marchesi, F.; Celesti, G.; Pesce, S.; Doni, A.; et al. The Fractalkine-Receptor Axis Improves Human Colorectal Cancer Prognosis by Limiting Tumor Metastatic Dissemination. J. Immunol. 2016, 196, 902-914. [CrossRef]

80. Liu, J.; Li, Y.; Zhu, X.; Li, Q.; Liang, X.; Xie, J.; Hu, S.; Peng, W.; Li, C. Increased CX3CL1 mRNA expression level is a positive prognostic factor in patients with lung adenocarcinoma. Oncol. Lett. 2019, 17, 4877-4890. [CrossRef]

81. Kehlen, A.; Greither, T.; Wach, S.; Nolte, E.; Kappler, M.; Bache, M.; Holzhausen, H.J.; Lautenschläger, C.; Göbel, S.; Würl, P.; et al. High coexpression of CCL2 and CX3CL1 is gender-specifically associated with good prognosis in soft tissue sarcoma patients. Int. J. Cancer 2014, 135, 2096-2106. [CrossRef] [PubMed]

82. Kee, J.Y.; Arita, Y.; Shinohara, K.; Ohashi, Y.; Sakurai, H.; Saiki, I.; Koizumi, K. Antitumor immune activity by chemokine CX3CL1 in an orthotopic implantation of lung cancer model in vivo. Mol. Clin. Oncol. 2013, 1, 35-40. [CrossRef] [PubMed]

83. Vitale, S.; Cambien, B.; Karimdjee, B.F.; Barthel, R.; Staccini, P.; Luci, C.; Breittmayer, V.; Anjuère, F.; Schmid-Alliana, A.; Schmid-Antomarchi, H. Tissue-specific differential antitumour effect of molecular forms of fractalkine in a mouse model of metastatic colon cancer. Gut 2007, 56, 365-372. [CrossRef] [PubMed]

84. Wu, C.T.; Chang, Y.H.; Lin, W.Y.; Chen, W.C.; Chen, M.F. TGF Beta1 Expression Correlates with Survival and Tumor Aggressiveness of Prostate Cancer. Ann. Surg. Oncol. 2015, 22 (Suppl. 3), S1587-S1593. [CrossRef]

85. Roy, L.O.; Poirier, M.B.; Fortin, D. Differential Expression and Clinical Significance of Transforming Growth Factor-Beta Isoforms in GBM Tumors. Int. J. Mol. Sci. 2018, 19, 1113. [CrossRef]

86. Tian, M.; Neil, J.R.; Schiemann, W.P. Transforming growth factor- $\beta$ and the hallmarks of cancer. Cell Signal. 2011, 23, 951-962. [CrossRef]

87. Sciumè, G.; Soriani, A.; Piccoli, M.; Frati, L.; Santoni, A.; Bernardini, G. CX3CR1/CX3CL1 axis negatively controls glioma cell invasion and is modulated by transforming growth factor- $\beta 1$. Neuro-Oncol. 2010, 12, 701-710. [CrossRef]

88. Castriconi, R.; Dondero, A.; Bellora, F.; Moretta, L.; Castellano, A.; Locatelli, F.; Corrias, M.V.; Moretta, A.; Bottino, C. Neuroblastoma-derived TGF- $\beta 1$ modulates the chemokine receptor repertoire of human resting NK cells. J. Immunol. 2013, 190, 5321-5328. [CrossRef] 
89. Regis, S.; Caliendo, F.; Dondero, A.; Casu, B.; Romano, F.; Loiacono, F.; Moretta, A.; Bottino, C.; Castriconi, R. TGF- $\beta 1$ Downregulates the Expression of CX3CR1 by Inducing miR-27a-5p in Primary Human NK Cells. Front. Immunol. 2017, 8, 868. [CrossRef]

90. Healy, C.G.; Simons, J.W.; Carducci, M.A.; DeWeese, T.L.; Bartkowski, M.; Tong, K.P.; Bolton, W.E. Impaired expression and function of signal-transducing zeta chains in peripheral T cells and natural killer cells in patients with prostate cancer. Cytometry 1998, 32, 109-119. [CrossRef]

91. Konjević, G.; Mirjacić Martinović, K.; Vuletić, A.; Jović, V.; Jurisić, V.; Babović, N.; Spuzić, I. Low expression of CD161 and NKG2D activating NK receptor is associated with impaired NK cell cytotoxicity in metastatic melanoma patients. Clin. Exp. Metastasis 2007, 24,1-11. [CrossRef] [PubMed]

92. Span, P.N.; Bussink, J. Biology of hypoxia. Semin. Nucl. Med. 2015, 45, 101-109. [CrossRef] [PubMed]

93. Panek, R.; Welsh, L.; Baker, L.C.J.; Schmidt, M.A.; Wong, K.H.; Riddell, A.M.; Koh, D.M.; Dunlop, A.; Mcquaid, D.; d'Arcy, J.A.; et al. Noninvasive Imaging of Cycling Hypoxia in Head and Neck Cancer Using Intrinsic Susceptibility MRI. Clin. Cancer Res. 2017, 23, 4233-4241. [CrossRef] [PubMed]

94. Ellingsen, C.; Ovrebø, K.M.; Galappathi, K.; Mathiesen, B.; Rofstad, E.K. $\mathrm{pO}_{2}$ fluctuation pattern and cycling hypoxia in human cervical carcinoma and melanoma xenografts. Int. J. Radiat. Oncol. Biol. Phys. 2012, 83, 1317-1323. [CrossRef]

95. Redler, G.; Epel, B.; Halpern, H.J. Principal component analysis enhances SNR for dynamic electron paramagnetic resonance oxygen imaging of cycling hypoxia in vivo. Magn. Reson. Med. 2014, 71, 440-450. [CrossRef]

96. Hashizume, H.; Baluk, P.; Morikawa, S.; McLean, J.W.; Thurston, G.; Roberge, S.; Jain, R.K.; McDonald, D.M. Openings between defective endothelial cells explain tumor vessel leakiness. Am. J. Pathol. 2000, 156, 1363-1380. [CrossRef]

97. Baluk, P.; Morikawa, S.; Haskell, A.; Mancuso, M.; McDonald, D.M. Abnormalities of basement membrane on blood vessels and endothelial sprouts in tumors. Am. J. Pathol. 2003, 163, 1801-1815. [CrossRef]

98. Baluk, P.; Hashizume, H.; McDonald, D.M. Cellular abnormalities of blood vessels as targets in cancer. Curr. Opin. Genet. Dev. 2005, 15, 102-111. [CrossRef]

99. Lanzen, J.; Braun, R.D.; Klitzman, B.; Brizel, D.; Secomb, T.W.; Dewhirst, M.W. Direct demonstration of instabilities in oxygen concentrations within the extravascular compartment of an experimental tumor. Cancer Res. 2006, 66, 2219-2223. [CrossRef]

100. Ren, L.; Yu, Y.; Wang, L.; Zhu, Z.; Lu, R.; Yao, Z. Hypoxia-induced CCL28 promotes recruitment of regulatory $\mathrm{T}$ cells and tumor growth in liver cancer. Oncotarget 2016, 7, 75763-75773. [CrossRef]

101. Riemann, A.; Reime, S.; Thews, O. Tumor Acidosis and Hypoxia Differently Modulate the Inflammatory Program: Measurements In Vitro and In Vivo. Neoplasia 2017, 19, 1033-1042. [CrossRef] [PubMed]

102. Tellier, C.; Desmet, D.; Petit, L.; Finet, L.; Graux, C.; Raes, M.; Feron, O.; Michiels, C. Cycling hypoxia induces a specific amplified inflammatory phenotype in endothelial cells and enhances tumor-promoting inflammation in vivo. Neoplasia 2015, 17, 66-78. [CrossRef] [PubMed]

103. El-Ghannam, D.M.; Arafa, M.; Badrawy, T. Mutations of p53 gene in breast cancer in the Egyptian province of Dakahliya. J. Oncol. Pharm. Pract. 2011, 17, 119-124. [CrossRef] [PubMed]

104. Milinkovic, V.; Bankovic, J.; Rakic, M.; Milosevic, N.; Stankovic, T.; Jokovic, M.; Milosevic, Z.; Skender-Gazibara, M.; Podolski-Renic, A.; Pesic, M.; et al. Genomic instability and p53 alterations in patients with malignant glioma. Exp. Mol. Pathol. 2012, 93, 200-206. [CrossRef] [PubMed]

105. Yilmaz, A.S.; Ozer, H.G.; Gillespie, J.L.; Allain, D.C.; Bernhardt, M.N.; Furlan, K.C.; Castro, L.T.; Peters, S.B.; Nagarajan, P.; Kang, S.Y.; et al. Differential mutation frequencies in metastatic cutaneous squamous cell carcinomas versus primary tumors. Cancer 2017, 123, 1184-1193. [CrossRef] [PubMed]

106. Chen, E.B.; Zhou, Z.J.; Xiao, K.; Zhu, G.Q.; Yang, Y.; Wang, B.; Zhou, S.L.; Chen, Q.; Yin, D.; Wang, Z.; et al. The miR-561-5p/CX3CL1 Signaling Axis Regulates Pulmonary Metastasis in Hepatocellular Carcinoma Involving CX3CR1+ Natural Killer Cells Infiltration. Theranostics 2019, 9, 4779-4794. [CrossRef] [PubMed]

107. Karan, D.; Lin, F.C.; Bryan, M.; Ringel, J.; Moniaux, N.; Lin, M.F.; Batra, S.K. Expression of ADAMs (a disintegrin and metalloproteases) and TIMP-3 (tissue inhibitor of metalloproteinase-3) in human prostatic adenocarcinomas. Int. J. Oncol. 2003, 23, 1365-1371. [CrossRef]

108. Sun, J.; Li, D.M.; Huang, J.; Liu, J.; Sun, B.; Fu, D.L.; Mao, G.S. The correlation between the expression of ADAM17, EGFR and Ki-67 in malignant gliomas. Eur. Rev. Med. Pharmacol. Sci. 2017, 21, 4595-4599. 
109. Matsubara, T.; Ono, T.; Yamanoi, A.; Tachibana, M.; Nagasue, N. Fractalkine-CX3CR1 axis regulates tumor cell cycle and deteriorates prognosis after radical resection for hepatocellular carcinoma. J. Surg. Oncol. 2007, 95, 241-249. [CrossRef]

110. Erreni, M.; Solinas, G.; Brescia, P.; Osti, D.; Zunino, F.; Colombo, P.; Destro, A.; Roncalli, M.; Mantovani, A.; Draghi, R.; et al. Human glioblastoma tumours and neural cancer stem cells express the chemokine CX3CL1 and its receptor CX3CR1. Eur. J. Cancer 2010, 46, 3383-3392. [CrossRef]

111. Su, Y.C.; Chang, H.; Sun, S.J.; Liao, C.Y.; Wang, L.Y.; Ko, J.L.; Chang, J.T. Differential impact of CX3CL1 on lung cancer prognosis in smokers and non-smokers. Mol. Carcinog. 2018, 57, 629-639. [CrossRef] [PubMed]

112. Xu, X.; Wang, Y.; Chen, J.; Ma, H.; Shao, Z.; Chen, H.; Jin, G. High expression of CX3CL1/CX3CR1 axis predicts a poor prognosis of pancreatic ductal adenocarcinoma. J. Gastrointest. Surg. 2012, 16, 1493-1498. [CrossRef] [PubMed]

113. Olsen, R.S.; Nijm, J.; Andersson, R.E.; Dimberg, J.; Wågsäter, D. Circulating inflammatory factors associated with worse long-term prognosis in colorectal cancer. World J. Gastroenterol. 2017, 23, 6212-6219. [CrossRef] [PubMed]

114. Uhlen, M.; Zhang, C.; Lee, S.; Sjöstedt, E.; Fagerberg, L.; Bidkhori, G.; Benfeitas, R.; Arif, M.; Liu, Z.; Edfors, F.; et al. A pathology atlas of the human cancer transcriptome. Science 2017, 357, eaan2507. [CrossRef] [PubMed]

115. Wei, L.M.; Cao, S.; Yu, W.D.; Liu, Y.L.; Wang, J.T. Overexpression of CX3CR1 is associated with cellular metastasis, proliferation and survival in gastric cancer. Oncol. Rep. 2015, 33, 615-624. [CrossRef]

116. Gaudin, F.; Nasreddine, S.; Donnadieu, A.C.; Emilie, D.; Combadière, C.; Prévot, S.; Machelon, V.; Balabanian, K. Identification of the chemokine CX3CL1 as a new regulator of malignant cell proliferation in epithelial ovarian cancer. PLoS ONE 2011, 6, e21546. [CrossRef]

117. Liu, J.F.; Tsao, Y.T.; Hou, C.H. Fractalkine/CX3CL1 induced intercellular adhesion molecule-1-dependent tumor metastasis through the CX3CR1/PI3K/Akt/NF- $k B$ pathway in human osteosarcoma. Oncotarget 2016, 8, 54136-54148. [CrossRef]

118. Meyer, M.; Reimand, J.; Lan, X.; Head, R.; Zhu, X.; Kushida, M.; Bayani, J.; Pressey, J.C.; Lionel, A.C.; Clarke, I.D.; et al. Single cell-derived clonal analysis of human glioblastoma links functional and genomic heterogeneity. Proc. Natl. Acad. Sci. USA 2015, 112, 851-856. [CrossRef]

119. Graeber, T.G.; Osmanian, C.; Jacks, T.; Housman, D.E.; Koch, C.J.; Lowe, S.W.; Giaccia, A.J. Hypoxia-mediated selection of cells with diminished apoptotic potential in solid tumours. Nature 1996, 379, 88-91. [CrossRef]

120. Kim, C.Y.; Tsai, M.H.; Osmanian, C.; Graeber, T.G.; Lee, J.E.; Giffard, R.G.; Di Paolo, J.A.; Peehl, D.M.; Giaccia, A.J. Selection of human cervical epithelial cells that possess reduced apoptotic potential to low-oxygen conditions. Cancer Res. 1997, 57, 4200-4204.

121. Huang, Q.; Li, F.; Liu, X.; Li, W.; Shi, W.; Liu, F.F.; O’Sullivan, B.; He, Z.; Peng, Y.; Tan, A.C.; et al. Caspase 3-mediated stimulation of tumor cell repopulation during cancer radiotherapy. Nat. Med. 2011, 17, 860-866. [CrossRef] [PubMed]

122. Willems, J.J.; Arnold, B.P.; Gregory, C.D. Sinister self-sacrifice: The contribution of apoptosis to malignancy. Front. Immunol. 2014, 5, 299. [CrossRef] [PubMed]

123. Gregory, C.D.; Pound, J.D. Cell death in the neighbourhood: Direct microenvironmental effects of apoptosis in normal and neoplastic tissues. J. Pathol. 2011, 223, 177-194. [CrossRef] [PubMed]

124. Weigert, A.; Tzieply, N.; von Knethen, A.; Johann, A.M.; Schmidt, H.; Geisslinger, G.; Brüne, B. Tumor cell apoptosis polarizes macrophages role of sphingosine-1-phosphate. Mol. Biol. Cell 2007, 18, 3810-3819. [CrossRef] [PubMed]

125. Gude, D.R.; Alvarez, S.E.; Paugh, S.W.; Mitra, P.; Yu, J.; Griffiths, R.; Barbour, S.E.; Milstien, S.; Spiegel, S. Apoptosis induces expression of sphingosine kinase 1 to release sphingosine-1-phosphate as a "come-and-get-me" signal. FASEB J. 2008, 22, 2629-2638. [CrossRef] [PubMed]

126. Weichand, B.; Weis, N.; Weigert, A.; Grossmann, N.; Levkau, B.; Brüne, B. Apoptotic cells enhance sphingosine-1-phosphate receptor 1 dependent macrophage migration. Eur. J. Immunol. 2013, 43, 3306-3313. [CrossRef]

127. Truman, L.A.; Ford, C.A.; Pasikowska, M.; Pound, J.D.; Wilkinson, S.J.; Dumitriu, I.E.; Melville, L.; Melrose, L.A.; Ogden, C.A.; Nibbs, R.; et al. CX3CL1/fractalkine is released from apoptotic lymphocytes to stimulate macrophage chemotaxis. Blood 2008, 112, 5026-5036. [CrossRef] 
128. Tsai, W.H.; Shih, C.H.; Feng, S.Y.; Li, I.T.; Chang, S.C.; Lin, Y.C.; Hsu, H.C. CX3CL1(+) microparticles mediate the chemoattraction of alveolar macrophages toward apoptotic acute promyelocytic leukemic cells. Cell Physiol. Biochem. 2014, 33, 594-604. [CrossRef]

129. Sokolowski, J.D.; Chabanon-Hicks, C.N.; Han, C.Z.; Heffron, D.S.; Mandell, J.W. Fractalkine is a "find-me" signal released by neurons undergoing ethanol-induced apoptosis. Front. Cell Neurosci. 2014, 8, 360. [CrossRef]

130. Arenberg, D.A.; Keane, M.P.; Di Giovine, B.; Kunkel, S.L.; Strom, S.R.; Burdick, M.D.; Iannettoni, M.D.; Strieter, R.M. Macrophage infiltration in human non-small-cell lung cancer: The role of CC chemokines. Cancer Immunol. Immunother. 2000, 49, 63-70. [CrossRef]

131. Mizutani, K.; Sud, S.; McGregor, N.A.; Martinovski, G.; Rice, B.T.; Craig, M.J.; Varsos, Z.S.; Roca, H.; Pienta, K.J. The chemokine $\mathrm{CCL}_{2}$ increases prostate tumor growth and bone metastasis through macrophage and osteoclast recruitment. Neoplasia 2009, 11, 1235-1242. [CrossRef] [PubMed]

132. Chen, Z.; Feng, X.; Herting, C.J.; Garcia, V.A.; Nie, K.; Pong, W.W.; Rasmussen, R.; Dwivedi, B.; Seby, S.; Wolf, S.A.; et al. Cellular and Molecular Identity of Tumor-Associated Macrophages in Glioblastoma. Cancer Res. 2017, 77, 2266-2278. [CrossRef] [PubMed]

133. Marelli, G.; Erreni, M.; Anselmo, A.; Taverniti, V.; Guglielmetti, S.; Mantovani, A.; Allavena, P. Heme-oxygenase-1 Production by Intestinal CX3CR1+ Macrophages Helps to Resolve Inflammation and Prevents Carcinogenesis. Cancer Res. 2017, 77, 4472-4485. [CrossRef] [PubMed]

134. Datar, I.; Qiu, X.; Ma, H.Z.; Yeung, M.; Aras, S.; de la Serna, I.; Al-Mulla, F.; Thiery, J.P.; Trumbly, R.; Fan, X.; et al. RKIP regulates CCL5 expression to inhibit breast cancer invasion and metastasis by controlling macrophage infiltration. Oncotarget 2015, 6, 39050-39061. [CrossRef] [PubMed]

135. Lan, Q.; Lai, W.; Zeng, Y.; Liu, L.; Li, S.; Jin, S.; Zhang, Y.; Luo, X.; Xu, H.; Lin, X.; et al. CCL26 Participates in the PRL-3-Induced Promotion of Colorectal Cancer Invasion by Stimulating Tumor-Associated Macrophage Infiltration. Mol. Cancer Ther. 2018, 17, 276-289. [CrossRef]

136. Miksa, M.; Amin, D.; Wu, R.; Ravikumar, T.S.; Wang, P. Fractalkine-induced MFG-E8 leads to enhanced apoptotic cell clearance by macrophages. Mol. Med. 2007, 13, 553-560. [CrossRef]

137. Fens, M.H.; Mastrobattista, E.; de Graaff, A.M.; Flesch, F.M.; Ultee, A.; Rasmussen, J.T.; Molema, G.; Storm, G.; Schiffelers, R.M. Angiogenic endothelium shows lactadherin-dependent phagocytosis of aged erythrocytes and apoptotic cells. Blood 2008, 111, 4542-4550. [CrossRef]

138. Stout, M.C.; Narayan, S.; Pillet, E.S.; Salvino, J.M.; Campbell, P.M. Inhibition of CX3CR1 reduces cell motility and viability in pancreatic adenocarcinoma epithelial cells. Biochem. Biophys. Res. Commun. 2018, 495, 2264-2269. [CrossRef]

139. Zhao, T.; Gao, S.; Wang, X.; Liu, J.; Duan, Y.; Yuan, Z.; Sheng, J.; Li, S.; Wang, F.; Yu, M.; et al. Hypoxia-inducible factor- $1 \alpha$ regulates chemotactic migration of pancreatic ductal adenocarcinoma cells through directly transactivating the CX3CR1 gene. PLoS ONE 2012, 7, e43399. [CrossRef]

140. Singh, S.K.; Mishra, M.K.; Singh, R. Hypoxia-inducible factor- $1 \alpha$ induces CX3CR1 expression and promotes the epithelial to mesenchymal transition (EMT) in ovarian cancer cells. J. Ovarian Res. 2019, 12, 42. [CrossRef]

141. Xiao, L.J.; Chen, Y.Y.; Lin, P.; Zou, H.F.; Lin, F.; Zhao, L.N.; Li, D.; Guo, L.; Tang, J.B.; Zheng, X.L.; et al. Hypoxia increases CX3CR1 expression via HIF-1 and NF- $\mathrm{KB}$ in androgen-independent prostate cancer cells. Int. J. Oncol. 2012, 41, 1827-1836. [CrossRef]

142. Barsoum, I.B.; Hamilton, T.K.; Li, X.; Cotechini, T.; Miles, E.A.; Siemens, D.R.; Graham, C.H. Hypoxia induces escape from innate immunity in cancer cells via increased expression of ADAM10: Role of nitric oxide. Cancer Res. 2011, 71, 7433-7441. [CrossRef] [PubMed]

143. Zheng, X.; Jiang, F.; Katakowski, M.; Kalkanis, S.N.; Hong, X.; Zhang, X.; Zhang, Z.G.; Yang, H.; Chopp, M. Inhibition of ADAM17 reduces hypoxia-induced brain tumor cell invasiveness. Cancer Sci. 2007, 98, 674-684. [CrossRef] [PubMed]

144. Szalad, A.; Katakowski, M.; Zheng, X.; Jiang, F.; Chopp, M. Transcription factor Sp1 induces ADAM17 and contributes to tumor cell invasiveness under hypoxia. J. Exp. Clin. Cancer Res. 2009, 28, 129. [CrossRef] [PubMed]

145. Wang, X.J.; Feng, C.W.; Li, M. ADAM17 mediates hypoxia-induced drug resistance in hepatocellular carcinoma cells through activation of EGFR/PI3K/Akt pathway. Mol. Cell Biochem. 2013, 380, 57-66. [CrossRef]

146. Chen, S.; Luo, D.; Streit, W.J.; Harrison, J.K. TGF-beta1 upregulates CX3CR1 expression and inhibits fractalkine-stimulated signaling in rat microglia. J. Neuroimmunol. 2002, 133, 46-55. [CrossRef] 
147. Desai, S.; Kumar, A.; Laskar, S.; Pandey, B.N. Cytokine profile of conditioned medium from human tumor cell lines after acute and fractionated doses of gamma radiation and its effect on survival of bystander tumor cells. Cytokine 2013, 61, 54-62. [CrossRef]

148. Castellana, D.; Zobairi, F.; Martinez, M.C.; Panaro, M.A.; Mitolo, V.; Freyssinet, J.M.; Kunzelmann, C. Membrane microvesicles as actors in the establishment of a favorable prostatic tumoral niche: A role for activated fibroblasts and CX3CL1-CX3CR1 axis. Cancer Res. 2009, 69, 785-793. [CrossRef]

149. Ferretti, E.; Bertolotto, M.; Deaglio, S.; Tripodo, C.; Ribatti, D.; Audrito, V.; Blengio, F.; Matis, S.; Zupo, S.; Rossi, D.; et al. A novel role of the CX3CR1/CX3CL1 system in the cross-talk between chronic lymphocytic leukemia cells and tumor microenvironment. Leukemia 2011, 25, 1268-1277. [CrossRef]

150. Chang, Y.S.; di Tomaso, E.; McDonald, D.M.; Jones, R.; Jain, R.K.; Munn, L.L. Mosaic blood vessels in tumors: Frequency of cancer cells in contact with flowing blood. Proc. Natl. Acad. Sci. USA 2000, 97, 14608-14613. [CrossRef]

151. Paoli, P.; Giannoni, E.; Chiarugi, P. Anoikis molecular pathways and its role in cancer progression. Biochim. Biophys. Acta 2013, 1833, 3481-3498. [CrossRef] [PubMed]

152. Valastyan, S.; Weinberg, R.A. Tumor metastasis: Molecular insights and evolving paradigms. Cell 2011, 147, 275-292. [CrossRef] [PubMed]

153. Jamieson-Gladney, W.L.; Zhang, Y.; Fong, A.M.; Meucci, O.; Fatatis, A. The chemokine receptor $\mathrm{CX}_{3} \mathrm{CR}_{1}$ is directly involved in the arrest of breast cancer cells to the skeleton. Breast Cancer Res. 2011, $13, \mathrm{R} 91$. [CrossRef] [PubMed]

154. Shen, F.; Zhang, Y.; Jernigan, D.L.; Feng, X.; Yan, J.; Garcia, F.U.; Meucci, O.; Salvino, J.M.; Fatatis, A. Novel Small-Molecule CX3CR1 Antagonist Impairs Metastatic Seeding and Colonization of Breast Cancer Cells. Mol. Cancer Res. 2016, 14, 518-527. [CrossRef]

155. Andre, F.; Cabioglu, N.; Assi, H.; Sabourin, J.C.; Delaloge, S.; Sahin, A.; Broglio, K.; Spano, J.P.; Combadiere, C.; Bucana, C.; et al. Expression of chemokine receptors predicts the site of metastatic relapse in patients with axillary node positive primary breast cancer. Ann. Oncol. 2006, 17, 945-951. [CrossRef]

156. Lv, C.Y.; Zhou, T.; Chen, W.; Yin, X.D.; Yao, J.H.; Zhang, Y.F. Preliminary study correlating CX3CL1/CX3CR1 expression with gastric carcinoma and gastric carcinoma perineural invasion. World J. Gastroenterol. 2014, 20, 4428-4432. [CrossRef]

157. Jones, F.S.; Rous, P. On the cause of the localistion of secondary tumors at points of injury. J. Exp. Med. 1914, 20, 404-412. [CrossRef]

158. DerHagopian, R.P.; Sugarbaker, E.V.; Ketcham, A. Inflammatory oncotaxis. JAMA 1978, 240, $374-375$. [CrossRef]

159. Tarozzo, G.; Campanella, M.; Ghiani, M.; Bulfone, A.; Beltramo, M. Expression of fractalkine and its receptor, CX3CR1, in response to ischaemia-reperfusion brain injury in the rat. Eur. J. Neurosci. 2002, 15, 1663-1668. [CrossRef]

160. Grosse, G.M.; Tryc, A.B.; Dirks, M.; Schuppner, R.; Pflugrad, H.; Lichtinghagen, R.; Weissenborn, K.; Worthmann, $\mathrm{H}$. The temporal dynamics of plasma fractalkine levels in ischemic stroke: Association with clinical severity and outcome. J. Neuroinflamm. 2014, 11, 74. [CrossRef]

161. Ishida, Y.; Gao, J.L.; Murphy, P.M. Chemokine receptor CX3CR1 mediates skin wound healing by promoting macrophage and fibroblast accumulation and function. J. Immunol. 2008, 180, 569-579. [CrossRef] [PubMed]

162. Getzin, T.; Krishnasamy, K.; Gamrekelashvili, J.; Kapanadze, T.; Limbourg, A.; Häger, C.; Napp, L.C.; Bauersachs, J.; Haller, H.; Limbourg, F.P. The chemokine receptor CX3CR1 coordinates monocyte recruitment and endothelial regeneration after arterial injury. EMBO Mol. Med. 2018, 10, 151-159. [CrossRef] [PubMed]

163. Koffi, E.; Moutardier, V.; Sauvanet, A.; Noun, R.; Fléjou, J.F.; Belghiti, J. Wound recurrence after resection of hepatocellular carcinoma. Liver Transpl. Surg. 1996, 2, 301-303. [CrossRef] [PubMed]

164. Walter, N.D.; Rice, P.L.; Redente, E.F.; Kauvar, E.F.; Lemond, L.; Aly, T.; Wanebo, K.; Chan, E.D. Wound healing after trauma may predispose to lung cancer metastasis: Review of potential mechanisms. Am. J. Respir Cell Mol. Biol. 2011, 44, 591-596. [CrossRef] [PubMed]

165. Modi, V.; Huang, K.G.; Sung, C.A. Wound-site metastasis in laparotomy of ovarian cancer. Gynecol. Minim. Invasive Ther. 2017, 6, 224-225. [CrossRef] [PubMed]

166. Yaghmour, W.; Kurdi, M.E.; Baeesa, S.S. De novo glioblastoma in the territory of a recent middle cerebral artery infarction and a residual meningioma: Pathogenesis revisited. World J. Surg. Oncol. 2016, 14, 112. [CrossRef] 
167. Scherzad, A.; Gehrke, T.; Meyer, T.; Ickrath, P.; Bregenzer, M.; Eiter, R.; Hagen, R.; Kleinsasser, N.; Hackenberg, S. Wound fluid enhances cancer cell proliferation via activation of STAT3 signal pathway in vitro. Oncol. Rep. 2019, 41, 2919-2926. [CrossRef]

168. Conley-LaComb, M.K.; Saliganan, A.; Kandagatla, P.; Chen, Y.Q.; Cher, M.L.; Chinni, S.R. PTEN loss mediated Akt activation promotes prostate tumor growth and metastasis via CXCL12/CXCR4 signaling. Mol. Cancer 2013, 12, 85. [CrossRef]

169. Xi, Y.; Qi, Z.; Ma, J.; Chen, Y. PTEN loss activates a functional AKT/CXCR4 signaling axis to potentiate tumor growth and lung metastasis in human osteosarcoma cells. Clin. Exp. Metastasis 2020, 37, 173-185. [CrossRef]

170. Wang, J.; Wang, H.; Cai, J.; Du, S.; Xin, B.; Wei, W.; Zhang, T.; Shen, X. Artemin regulates CXCR4 expression to induce migration and invasion in pancreatic cancer cells through activation of NF- $\mathrm{KB}$ signaling. Exp. Cell Res. 2018, 365, 12-23. [CrossRef]

171. Zhu, M.; Guo, J.; Xia, H.; Li, W.; Lu, Y.; Dong, X.; Chen, Y.; Xie, X.; Fu, S.; Li, M. Alpha-fetoprotein activates AKT/mTOR signaling to promote CXCR4 expression and migration of hepatoma cells. Oncoscience 2015, 2, 59-70. [CrossRef] [PubMed]

172. Teixidó, J.; Martínez-Moreno, M.; Díaz-Martínez, M.; Sevilla-Movilla, S. The good and bad faces of the CXCR4 chemokine receptor. Int. J. Biochem. Cell Biol. 2018, 95, 121-131. [CrossRef] [PubMed]

173. Wada, A.; Ito, A.; Iitsuka, H.; Tsuneyama, K.; Miyazono, T.; Murakami, J.; Shibahara, N.; Sakurai, H.; Saiki, I.; Nakayama, T.; et al. Role of chemokine CX3CL1 in progression of multiple myeloma via CX3CR1 in bone microenvironments. Oncol. Rep. 2015, 33, 2935-2939. [CrossRef] [PubMed]

174. Locatelli, M.; Boiocchi, L.; Ferrero, S.; Martinelli Boneschi, F.; Zavanone, M.; Pesce, S.; Allavena, P.; Maria Gaini, S.; Bello, L.; Mantovani, A. Human glioma tumors express high levels of the chemokine receptor CX3CR1. Eur. Cytokine Netw. 2010, 21, 27-33. [CrossRef] [PubMed]

175. Seifert, M.; Garbe, M.; Friedrich, B.; Mittelbronn, M.; Klink, B. Comparative transcriptomics reveals similarities and differences between astrocytoma grades. BMC Cancer 2015, 15, 952. [CrossRef]

176. Sharma, I.; Singh, A.; Sharma, K.C.; Saxena, S. Gene Expression Profiling of Chemokines and Their Receptors in Low and High Grade Astrocytoma. Asian Pac. J. Cancer Prev. 2017, 18, 1307-1313.

177. Lin, C.; McGough, R.; Aswad, B.; Block, J.A.; Terek, R. Hypoxia induces HIF-1alpha and VEGF expression in chondrosarcoma cells and chondrocytes. J. Orthop. Res. 2004, 22, 1175-1181. [CrossRef]

178. Cesário, J.M.; Brito, R.B.; Malta, C.S.; Silva, C.S.; Matos, Y.S.; Kunz, T.C.; Urbano, J.J.; Oliveira, L.V.; Dalboni, M.A.; Dellê, H. A simple method to induce hypoxia-induced vascular endothelial growth factor-A (VEGF-A) expression in T24 human bladder cancer cells. In Vitro Cell Dev. Biol. Anim. 2017, 53, 272-276. [CrossRef]

179. Matsuura, Y.; Wada, H.; Eguchi, H.; Gotoh, K.; Kobayashi, S.; Kinoshita, M.; Kubo, M.; Hayashi, K.; Iwagami, Y.; Yamada, D.; et al. Exosomal miR-155 Derived from Hepatocellular Carcinoma Cells Under Hypoxia Promotes Angiogenesis in Endothelial Cells. Dig. Dis Sci. 2019, 64, 792-802. [CrossRef]

180. Gomes, F.G.; Nedel, F.; Alves, A.M.; Nör, J.E.; Tarquinio, S.B. Tumor angiogenesis and lymphangiogenesis: Tumor/endothelial crosstalk and cellular/microenvironmental signaling mechanisms. Life Sci. 2013, 92, 101-107. [CrossRef]

181. Lohela, M.; Bry, M.; Tammela, T.; Alitalo, K. VEGFs and receptors involved in angiogenesis versus lymphangiogenesis. Curr. Opin. Cell Biol. 2009, 21, 154-165. [CrossRef] [PubMed]

182. Corliss, B.A.; Azimi, M.S.; Munson, J.M.; Peirce, S.M.; Murfee, W.L. Macrophages: An Inflammatory Link Between Angiogenesis and Lymphangiogenesis. Microcirculation 2016, 23, 95-121. [CrossRef] [PubMed]

183. Reed, J.R.; Stone, M.D.; Beadnell, T.C.; Ryu, Y.; Griffin, T.J.; Schwertfeger, K.L. Fibroblast growth factor receptor 1 activation in mammary tumor cells promotes macrophage recruitment in a CX3CL1-dependent manner. PLoS ONE 2012, 7, e45877. [CrossRef] [PubMed]

184. Li, F.; Wang, Z.; Liu, Y.; Li, J. Down-regulation of fractalkine inhibits the in vitro and in vivo angiogenesis of the hepatocellular carcinoma HepG2 cells. Oncol. Rep. 2010, 24, 669-675.

185. Schmall, A.; Al-Tamari, H.M.; Herold, S.; Kampschulte, M.; Weigert, A.; Wietelmann, A.; Vipotnik, N.; Grimminger, F.; Seeger, W.; Pullamsetti, S.S.; et al. Macrophage and cancer cell cross-talk via CCR2 and CX3CR1 is a fundamental mechanism driving lung cancer. Am. J. Respir. Crit. Care Med. 2015, 191, 437-447. [CrossRef] [PubMed]

186. Ren, T.; Chen, Q.; Tian, Z.; Wei, H. Down-regulation of surface fractalkine by RNA interference in B16 melanoma reduced tumor growth in mice. Biochem. Biophys. Res. Commun. 2007, 364, 978-984. [CrossRef] 
187. Marchica, V.; Toscani, D.; Corcione, A.; Bolzoni, M.; Storti, P.; Vescovini, R.; Ferretti, E.; Dalla Palma, B.; Vicario, E.; Accardi, F.; et al. Bone Marrow CX3CL1/Fractalkine is a New Player of the Pro-Angiogenic Microenvironment in Multiple Myeloma Patients. Cancers 2019, 11, 321. [CrossRef]

188. Zheng, J.; Yang, M.; Shao, J.; Miao, Y.; Han, J.; Du, J. Chemokine receptor CX3CR1 contributes to macrophage survival in tumor metastasis. Mol. Cancer 2013, 12, 141. [CrossRef]

189. Lee, Y.C.; Chang, Y.C.; Wu, C.C.; Huang, C.C. Hypoxia-Preconditioned Human Umbilical Vein Endothelial Cells Protect Against Neurovascular Damage After Hypoxic Ischemia in Neonatal Brain. Mol. Neurobiol. 2018, 55, 7743-7757. [CrossRef]

190. Mizutani, N.; Sakurai, T.; Shibata, T.; Uchida, K.; Fujita, J.; Kawashima, R.; Kawamura, Y.I.; Toyama-Sorimachi, N.; Imai, T.; Dohi, T. Dose-dependent differential regulation of cytokine secretion from macrophages by fractalkine. J. Immunol. 2007, 179, 7478-7487. [CrossRef]

191. Jackaman, C.; Yeoh, T.L.; Acuil, M.L.; Gardner, J.K.; Nelson, D.J. Murine mesothelioma induces locally-proliferating IL-10(+)TNF- $\alpha(+)$ CD206(-)CX3CR1(+) M3 macrophages that can be selectively depleted by chemotherapy or immunotherapy. Oncoimmunology 2016, 5, e1173299. [CrossRef] [PubMed]

192. Ding, P.; Wang, W.; Wang, J.; Yang, Z.; Xue, L. Expression of tumor-associated macrophage in progression of human glioma. Cell Biochem. Biophys. 2014, 70, 1625-1631. [CrossRef] [PubMed]

193. Xu, W.; Zhao, X.; Daha, M.R.; van Kooten, C. Reversible differentiation of pro- and anti-inflammatory macrophages. Mol. Immunol. 2013, 53, 179-186. [CrossRef] [PubMed]

194. Sawanobori, Y.; Ueha, S.; Kurachi, M.; Shimaoka, T.; Talmadge, J.E.; Abe, J.; Shono, Y.; Kitabatake, M.; Kakimi, K.; Mukaida, N.; et al. Chemokine-mediated rapid turnover of myeloid-derived suppressor cells in tumor-bearing mice. Blood 2008, 111, 5457-5466. [CrossRef]

195. Wong, K.L.; Tai, J.J.; Wong, W.C.; Han, H.; Sem, X.; Yeap, W.H.; Kourilsky, P.; Wong, S.C. Gene expression profiling reveals the defining features of the classical, intermediate, and nonclassical human monocyte subsets. Blood 2011, 118, e16-e31. [CrossRef]

196. Mandl, M.; Schmitz, S.; Weber, C.; Hristov, M. Characterization of the CD14++CD16+ monocyte population in human bone marrow. PLoS ONE 2014, 9, e112140. [CrossRef]

197. Ancuta, P.; Rao, R.; Moses, A.; Mehle, A.; Shaw, S.K.; Luscinskas, F.W.; Gabuzda, D. Fractalkine preferentially mediates arrest and migration of CD16+ monocytes. J. Exp. Med. 2003, 197, 1701-1707. [CrossRef]

198. Sánchez-Torres, C.; García-Romo, G.S.; Cornejo-Cortés, M.A.; Rivas-Carvalho, A.; Sánchez-Schmitz, G. CD16+ and CD16- human blood monocyte subsets differentiate in vitro to dendritic cells with different abilities to stimulate CD4+ T cells. Int. Immunol. 2001, 13, 1571-1581. [CrossRef]

199. Ancuta, P.; Moses, A.; Gabuzda, D. Transendothelial migration of CD16+ monocytes in response to fractalkine under constitutive and inflammatory conditions. Immunobiology 2004, 209, 11-20. [CrossRef]

200. Goda, S.; Imai, T.; Yoshie, O.; Yoneda, O.; Inoue, H.; Nagano, Y.; Okazaki, T.; Imai, H.; Bloom, E.T.; Domae, N.; et al. CX3C-chemokine, fractalkine-enhanced adhesion of THP-1 cells to endothelial cells through integrin-dependent and -independent mechanisms. J. Immunol. 2000, 164, 4313-4320. [CrossRef]

201. Althoff, K.; Reddy, P.; Voltz, N.; Rose-John, S.; Müllberg, J. Shedding of interleukin-6 receptor and tumor necrosis factor alpha. Contribution of the stalk sequence to the cleavage pattern of transmembrane proteins. Eur. J. Biochem. 2000, 267, 2624-2631. [CrossRef] [PubMed]

202. Rennert, K.; Heisig, K.; Groeger, M.; Wallert, M.; Funke, H.; Lorkowski, S.; Huber, O.; Mosig, A.S. Recruitment of CD16(+) monocytes to endothelial cells in response to LPS-treatment and concomitant TNF release is regulated by CX3CR1 and interfered by soluble fractalkine. Cytokine 2016, 83, 41-52. [CrossRef] [PubMed]

203. Green, S.R.; Han, K.H.; Chen, Y.; Almazan, F.; Charo, I.F.; Miller, Y.I.; Quehenberger, O. The CC chemokine MCP-1 stimulates surface expression of CX3CR1 and enhances the adhesion of monocytes to fractalkine/CX3CL1 via p38 MAPK. J. Immunol. 2006, 176, 7412-7420. [CrossRef] [PubMed]

204. Vitale, S.; Schmid-Alliana, A.; Breuil, V.; Pomeranz, M.; Millet, M.A.; Rossi, B.; Schmid-Antomarchi, H. Soluble fractalkine prevents monocyte chemoattractant protein-1-induced monocyte migration via inhibition of stress-activated protein kinase 2/p38 and matrix metalloproteinase activities. J. Immunol. 2004, 172, 585-592. [CrossRef] [PubMed]

205. Ancuta, P.; Wang, J.; Gabuzda, D. CD16+ monocytes produce IL-6, CCL2, and matrix metalloproteinase-9 upon interaction with CX3CL1-expressing endothelial cells. J. Leukoc. Biol. 2006, 80, 1156-1164. [CrossRef] [PubMed] 
206. Park, Y.; Lee, J.; Kwak, J.Y.; Noh, K.; Yim, E.; Kim, H.K.; Kim, Y.J.; Broxmeyer, H.E.; Kim, J.A. Fractalkine induces angiogenic potential in CX3CR1-expressing monocytes. J. Leukoc. Biol. 2018, 103, 53-66. [CrossRef]

207. Chen, L.; Liu, G.Q.; Wu, H.Y.; Jin, J.; Yin, X.; Li, D.; Lu, P.R. Monocyte chemoattractant protein 1 and fractalkine play opposite roles in angiogenesis via recruitment of different macrophage subtypes. Int. J. Ophthalmol. 2018, 11, 216-222.

208. Hattermann, K.; Sebens, S.; Helm, O.; Schmitt, A.D.; Mentlein, R.; Mehdorn, H.M.; Held-Feindt, J. Chemokine expression profile of freshly isolated human glioblastoma-associated macrophages/microglia. Oncol. Rep. 2014, 32, 270-276. [CrossRef]

209. Held-Feindt, J.; Hattermann, K.; Müerköster, S.S.; Wedderkopp, H.; Knerlich-Lukoschus, F.; Ungefroren, H.; Mehdorn, H.M.; Mentlein, R. CX3CR1 promotes recruitment of human glioma-infiltrating microglia/macrophages (GIMs). Exp. Cell Res. 2010, 316, 1553-1566. [CrossRef]

210. Pong, W.W.; Higer, S.B.; Gianino, S.M.; Emnett, R.J.; Gutmann, D.H. Reduced microglial CX3CR1 expression delays neurofibromatosis-1 glioma formation. Ann. Neurol. 2013, 73, 303-308. [CrossRef]

211. Resende, F.F.; Bai, X.; Del Bel, E.A.; Kirchhoff, F.; Scheller, A.; Titze-de-Almeida, R. Evaluation of $\operatorname{TgH}(\mathrm{CX} 3 \mathrm{CR} 1-\mathrm{EGFP})$ mice implanted with mCherry-GL261 cells as an in vivo model for morphometrical analysis of glioma-microglia interaction. BMC Cancer 2016, 16, 72. [CrossRef] [PubMed]

212. Liu, C.; Luo, D.; Streit, W.J.; Harrison, J.K. CX3CL1 and CX3CR1 in the GL261 murine model of glioma: CX3CR1 deficiency does not impact tumor growth or infiltration of microglia and lymphocytes. J. Neuroimmunol. 2008, 198, 98-105. [CrossRef] [PubMed]

213. Feng, X.; Szulzewsky, F.; Yerevanian, A.; Chen, Z.; Heinzmann, D.; Rasmussen, R.D.; Alvarez-Garcia, V.; Kim, Y.; Wang, B.; Tamagno, I.; et al. Loss of CX3CR1 increases accumulation of inflammatory monocytes and promotes gliomagenesis. Oncotarget 2015, 6, 15077-15094. [CrossRef]

214. Rodero, M.; Marie, Y.; Coudert, M.; Blondet, E.; Mokhtari, K.; Rousseau, A.; Raoul, W.; Carpentier, C.; Sennlaub, F.; Deterre, P.; et al. Polymorphism in the microglial cell-mobilizing CX3CR1 gene is associated with survival in patients with glioblastoma. J. Clin. Oncol. 2008, 26, 5957-5964. [CrossRef] [PubMed]

215. Pham, K.; Luo, D.; Liu, C.; Harrison, J.K. CCL5, CCR1 and CCR5 in murine glioblastoma: Immune cell infiltration and survival rates are not dependent on individual expression of either CCR1 or CCR5. J. Neuroimmunol. 2012, 246, 10-17. [CrossRef] [PubMed]

216. Mizuno, T.; Kawanokuchi, J.; Numata, K.; Suzumura, A. Production and neuroprotective functions of fractalkine in the central nervous system. Brain Res. 2003, 979, 65-70. [CrossRef]

217. Lyons, A.; Lynch, A.M.; Downer, E.J.; Hanley, R.; O'Sullivan, J.B.; Smith, A.; Lynch, M.A. Fractalkine-induced activation of the phosphatidylinositol-3 kinase pathway attentuates microglial activation in vivo and in vitro. J. Neurochem. 2009, 110, 1547-1556. [CrossRef]

218. Liu, Y.; Zhao, T.; Yang, Z.; Li, Q. CX3CR1 RNAi inhibits hypoxia-induced microglia activation via p38MAPK/PKC pathway. Int. J. Exp. Pathol. 2014, 95, 153-157. [CrossRef]

219. Boyault, S.; Bianchi, A.; Moulin, D.; Morin, S.; Francois, M.; Netter, P.; Terlain, B.; Bordji, K. 15-Deoxy-delta(12,14)-prostaglandin J(2) inhibits IL-1beta-induced IKK enzymatic activity and IkappaBalpha degradation in rat chondrocytes through a PPARgamma-independent pathway. FEBS Lett. 2004, 572, 33-40. [CrossRef]

220. Fathima Hurmath, K.; Ramaswamy, P.; Nandakumar, D.N. IL-1 $\beta$ microenvironment promotes proliferation, migration, and invasion of human glioma cells. Cell Biol. Int. 2014, 38, 1415-1422. [CrossRef]

221. Jiang, J.; Guo, W.; Liang, X. Phenotypes, accumulation, and functions of myeloid-derived suppressor cells and associated treatment strategies in cancer patients. Hum. Immunol. 2014, 75, 1128-1137. [CrossRef] [PubMed]

222. Zhao, W.; Xu, Y.; Xu, J.; Wu, D.; Zhao, B.; Yin, Z.; Wang, X. Subsets of myeloid-derived suppressor cells in hepatocellular carcinoma express chemokines and chemokine receptors differentially. Int. Immunopharmacol. 2015, 26, 314-321. [CrossRef] [PubMed]

223. Ishida, Y.; Kido, A.; Akahane, M.; Kishi, S.; Tsukamoto, S.; Fujii, H.; Honoki, K.; Tanaka, Y. Mesenchymal stem cells up-regulate the invasive potential of prostate cancer cells via the eotaxin-3/CCR3 axis. Pathol. Res. Pract. 2018, 214, 1297-1302. [CrossRef] [PubMed]

224. Nakayama, T.; Watanabe, Y.; Oiso, N.; Higuchi, T.; Shigeta, A.; Mizuguchi, N.; Katou, F.; Hashimoto, K.; Kawada, A.; Yoshie, O. Eotaxin-3/CC chemokine ligand 26 is a functional ligand for CX3CR1. J. Immunol. 2010, 185, 6472-6479. [CrossRef] [PubMed] 
225. Chiu, D.K.; Xu, I.M.; Lai, R.K.; Tse, A.P.; Wei, L.L.; Koh, H.Y.; Li, L.L.; Lee, D.; Lo, R.C.; Wong, C.M.; et al. Hypoxia induces myeloid-derived suppressor cell recruitment to hepatocellular carcinoma through chemokine (C-C motif) ligand 26. Hepatology 2016, 64, 797-813. [CrossRef]

226. Raber, P.L.; Thevenot, P.; Sierra, R.; Wyczechowska, D.; Halle, D.; Ramirez, M.E.; Ochoa, A.C.; Fletcher, M.; Velasco, C.; Wilk, A.; et al. Subpopulations of myeloid-derived suppressor cells impair T cell responses through independent nitric oxide-related pathways. Int. J. Cancer 2014, 134, 2853-2864. [CrossRef]

227. Schlecker, E.; Stojanovic, A.; Eisen, C.; Quack, C.; Falk, C.S.; Umansky, V.; Cerwenka, A. Tumor-infiltrating monocytic myeloid-derived suppressor cells mediate CCR5-dependent recruitment of regulatory $\mathrm{T}$ cells favoring tumor growth. J. Immunol. 2012, 189, 5602-5611. [CrossRef]

228. Frydrychowicz, M.; Boruczkowski, M.; Kolecka-Bednarczyk, A.; Dworacki, G. The Dual Role of Treg in Cancer. Scand. J. Immunol. 2017, 86, 436-443. [CrossRef]

229. Cobbs, C.S.; Harkins, L.; Samanta, M.; Gillespie, G.Y.; Bharara, S.; King, P.H.; Nabors, L.B.; Cobbs, C.G.; Britt, W.J. Human cytomegalovirus infection and expression in human malignant glioma. Cancer Res. 2002, $62,3347-3350$.

230. Dos Santos, C.J.; Stangherlin, L.M.; Figueiredo, E.G.; Corrêa, C.; Teixeira, M.J.; da Silva, M.C. High prevalence of HCMV and viral load in tumor tissues and peripheral blood of glioblastoma multiforme patients. J. Med. Virol. 2014, 86, 1953-1961. [CrossRef]

231. Shamran, H.A.; Kadhim, H.S.; Hussain, A.R.; Kareem, A.; Taub, D.D.; Price, R.L.; Nagarkatti, M.; Nagarkatti, P.S.; Singh, U.P. Detection of human cytomegalovirus in different histopathological types of glioma in Iraqi patients. Biomed. Res. Int. 2015, 2015. [CrossRef] [PubMed]

232. Soroceanu, L.; Matlaf, L.; Bezrookove, V.; Harkins, L.; Martinez, R.; Greene, M.; Soteropoulos, P.; Cobbs, C.S. Human cytomegalovirus US28 found in glioblastoma promotes an invasive and angiogenic phenotype. Cancer Res. 2011, 71, 6643-6653. [CrossRef] [PubMed]

233. Costa, H.; Xu, X.; Overbeek, G.; Vasaikar, S.; Patro, C.P.; Kostopoulou, O.N.; Jung, M.; Shafi, G.; Ananthaseshan, S.; Tsipras, G.; et al. Human cytomegalovirus may promote tumour progression by upregulating arginase-2. Oncotarget 2016, 7, 47221-47231. [CrossRef] [PubMed]

234. Batich, K.A.; Reap, E.A.; Archer, G.E.; Sanchez-Perez, L.; Nair, S.K.; Schmittling, R.J.; Norberg, P.; Xie, W.; Herndon, J.E., 2nd; Healy, P.; et al. Long-term Survival in Glioblastoma with Cytomegalovirus pp65-Targeted Vaccination. Clin. Cancer Res. 2017, 23, 1898-1909. [CrossRef] [PubMed]

235. Stragliotto, G.; Rahbar, A.; Solberg, N.W.; Lilja, A.; Taher, C.; Orrego, A.; Bjurman, B.; Tammik, C.; Skarman, P.; Peredo, I.; et al. Effects of valganciclovir as an add-on therapy in patients with cytomegalovirus-positive glioblastoma: A randomized, double-blind, hypothesis-generating study. Int. J. Cancer 2013, 133, 1204-1213. [CrossRef] [PubMed]

236. Johnson, T.S.; Abrams, Z.B.; Mo, X.; Zhang, Y.; Huang, K. Lack of human cytomegalovirus expression in single cells from glioblastoma tumors and cell lines. J. Neurovirol. 2017, 23, 671-678. [CrossRef]

237. Loit, M.P.; Adle-Biassette, H.; Bouazza, S.; Mazeron, M.C.; Manivet, P.; Lehmann-Che, J.; Teissier, N.; Mandonnet, E.; Molina, J.M. Multimodal techniques failed to detect cytomegalovirus in human glioblastoma samples. J. Neurovirol. 2019, 25, 50-56. [CrossRef]

238. Staras, S.A.; Dollard, S.C.; Radford, K.W.; Flanders, W.D.; Pass, R.F.; Cannon, M.J. Seroprevalence of cytomegalovirus infection in the United States, 1988-1994. Clin. Infect. Dis. 2006, 43, 1143-1151. [CrossRef]

239. Lübeck, P.R.; Doerr, H.W.; Rabenau, H.F. Epidemiology of human cytomegalovirus (HCMV) in an urban region of Germany: What has changed? Med. Microbiol. Immunol. 2010, 199, 53-60. [CrossRef]

240. Humby, M.S.; O'Connor, C.M. Human Cytomegalovirus US28 Is Important for Latent Infection of Hematopoietic Progenitor Cells. J. Virol. 2015, 90, 2959-2970. [CrossRef]

241. Crawford, L.B.; Caposio, P.; Kreklywich, C.; Pham, A.H.; Hancock, M.H.; Jones, T.A.; Smith, P.P.; Yurochko, A.D.; Nelson, J.A.; Streblow, D.N. Human Cytomegalovirus US28 Ligand Binding Activity Is Required for Latency in CD34+ Hematopoietic Progenitor Cells and Humanized NSG Mice. MBio 2019, 10, e01889. [CrossRef] [PubMed]

242. Hargett, D.; Shenk, T.E. Experimental human cytomegalovirus latency in CD14+ monocytes. Proc. Natl. Acad. Sci. USA 2010, 107, 20039-20044. [CrossRef] [PubMed]

243. Daley-Bauer, L.P.; Roback, L.J.; Wynn, G.M.; Mocarski, E.S. Cytomegalovirus hijacks CX3CR1(hi) patrolling monocytes as immune-privileged vehicles for dissemination in mice. Cell Host Microbe 2014, 15, 351-362. [CrossRef] [PubMed] 
244. Krishna, B.A.; Poole, E.L.; Jackson, S.E.; Smit, M.J.; Wills, M.R.; Sinclair, J.H. Latency-Associated Expression of Human Cytomegalovirus US28 Attenuates Cell Signaling Pathways To Maintain Latent Infection. MBio 2017, 8, e01754-e01717. [CrossRef]

245. Krishna, B.A.; Humby, M.S.; Miller, W.E.; O'Connor, C.M. Human cytomegalovirus G protein-coupled receptor US28 promotes latency by attenuating c-fos. Proc. Natl. Acad. Sci. USA 2019, 116, 1755-1764. [CrossRef]

246. Vomaske, J.; Melnychuk, R.M.; Smith, P.P.; Powell, J.; Hall, L.; DeFilippis, V.; Früh, K.; Smit, M.; Schlaepfer, D.D.; Nelson, J.A.; et al. Differential ligand binding to a human cytomegalovirus chemokine receptor determines cell type-specific motility. PLoS Pathog. 2009, 5, e1000304. [CrossRef]

247. Burg, J.S.; Ingram, J.R.; Venkatakrishnan, A.J.; Jude, K.M.; Dukkipati, A.; Feinberg, E.N.; Angelini, A.; Waghray, D.; Dror, R.O.; Ploegh, H.L.; et al. Structural biology. Structural basis for chemokine recognition and activation of a viral G protein-coupled receptor. Science 2015, 347, 1113-1117. [CrossRef]

248. Hjortø, G.M.; Kiilerich-Pedersen, K.; Selmeczi, D.; Kledal, T.N.; Larsen, N.B. Human cytomegalovirus chemokine receptor US28 induces migration of cells on a CX3CL1-presenting surface. J. Gen. Virol. 2013, 94, 1111-1120. [CrossRef]

249. Kledal, T.N.; Rosenkilde, M.M.; Schwartz, T.W. Selective recognition of the membrane-bound CX3C chemokine, fractalkine, by the human cytomegalovirus-encoded broad-spectrum receptor US28. FEBS Lett. 1998, 441, 209-214. [CrossRef]

250. Haskell, C.A.; Cleary, M.D.; Charo, I.F. Unique role of the chemokine domain of fractalkine in cell capture. Kinetics of receptor dissociation correlate with cell adhesion. J. Biol. Chem. 2000, 275, 34183-34189. [CrossRef]

251. Noriega, V.M.; Gardner, T.J.; Redmann, V.; Bongers, G.; Lira, S.A.; Tortorella, D. Human cytomegalovirus US28 facilitates cell-to-cell viral dissemination. Viruses 2014, 6, 1202-1218. [CrossRef] [PubMed]

252. Iga, M.; Boissonnas, A.; Mahé, B.; Bonduelle, O.; Combadière, C.; Combadière, B. Single CX3CL1-Ig DNA administration enhances T cell priming in vivo. Vaccine 2007, 25, 4554-4563. [CrossRef] [PubMed]

253. Zeng, Y.; Huebener, N.; Fest, S.; Weixler, S.; Schroeder, U.; Gaedicke, G.; Xiang, R.; Schramm, A.; Eggert, A.; Reisfeld, R.A.; et al. Fractalkine (CX3CL1)- and interleukin-2-enriched neuroblastoma microenvironment induces eradication of metastases mediated by T cells and natural killer cells. Cancer Res. 2007, 67, 2331-2338. [CrossRef] [PubMed]

254. Siddiqui, I.; Erreni, M.; van Brakel, M.; Debets, R.; Allavena, P. Enhanced recruitment of genetically modified CX3CR1-positive human T cells into Fractalkine/CX3CL1 expressing tumors: Importance of the chemokine gradient. J. Immunother. Cancer 2016, 4, 21. [CrossRef]

255. Nukiwa, M.; Andarini, S.; Zaini, J.; Xin, H.; Kanehira, M.; Suzuki, T.; Fukuhara, T.; Mizuguchi, H.; Hayakawa, T.; Saijo, Y.; et al. Dendritic cells modified to express fractalkine/CX3CL1 in the treatment of preexisting tumors. Eur. J. Immunol. 2006, 36, 1019-1027. [CrossRef]

256. Burkholder, B.; Huang, R.Y.; Burgess, R.; Luo, S.; Jones, V.S.; Zhang, W.; Lv, Z.Q.; Gao, C.Y.; Wang, B.L.; Zhang, Y.M.; et al. Tumor-induced perturbations of cytokines and immune cell networks. Biochim. Biophys. Acta 2014, 1845, 182-201. [CrossRef]

257. Speranza, M.C.; Passaro, C.; Ricklefs, F.; Kasai, K.; Klein, S.R.; Nakashima, H.; Kaufmann, J.K.; Ahmed, A.K.; Nowicki, M.O.; Obi, P.; et al. Preclinical investigation of combined gene-mediated cytotoxic immunotherapy and immune checkpoint blockade in glioblastoma. Neuro-Oncol. 2018, 20, 225-235. [CrossRef]

(C) 2020 by the authors. Licensee MDPI, Basel, Switzerland. This article is an open access article distributed under the terms and conditions of the Creative Commons Attribution (CC BY) license (http://creativecommons.org/licenses/by/4.0/). 